
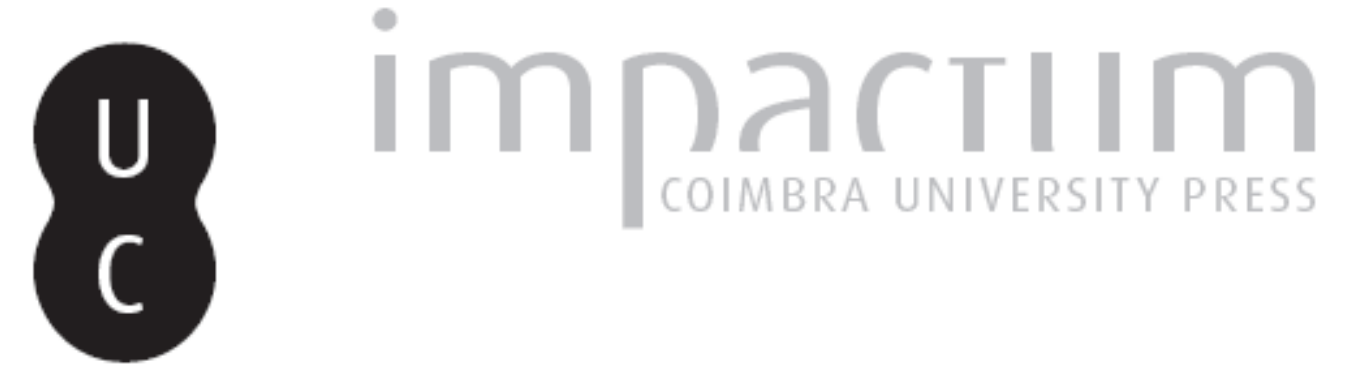

\title{
Trayectoria de las rentas monásticas y del sistema agrario de Galicia desde la segunda mitad del XVI a 1835
}

Autor(es): $\quad$ Saavedra, Pegerto

$\begin{array}{ll}\text { Publicado por: } & \text { Instituto de História Económica e Social, Faculdade de Letras da } \\ \text { Universidade de Coimbra }\end{array}$

URL

persistente:

DOI: $\quad$ DOI:http://dx.doi.org/10.14195/0870-4147_41_5

Accessed : $\quad$ 26-Apr-2023 13:33:36

A navegação consulta e descarregamento dos títulos inseridos nas Bibliotecas Digitais UC Digitalis, UC Pombalina e UC Impactum, pressupõem a aceitação plena e sem reservas dos Termos e Condições de Uso destas Bibliotecas Digitais, disponíveis em https://digitalis.uc.pt/pt-pt/termos.

Conforme exposto nos referidos Termos e Condições de Uso, o descarregamento de títulos de acesso restrito requer uma licença válida de autorização devendo o utilizador aceder ao(s) documento(s) a partir de um endereço de IP da instituição detentora da supramencionada licença.

Ao utilizador é apenas permitido o descarregamento para uso pessoal, pelo que o emprego do(s) título(s) descarregado(s) para outro fim, designadamente comercial, carece de autorização do respetivo autor ou editor da obra.

Na medida em que todas as obras da UC Digitalis se encontram protegidas pelo Código do Direito de Autor e Direitos Conexos e demais legislação aplicável, toda a cópia, parcial ou total, deste documento, nos casos em que é legalmente admitida, deverá conter ou fazer-se acompanhar por este aviso.

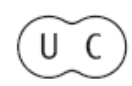





\title{
Trayectoria de las rentas monásticas y del sistema agrario de Galicia desde la segunda mitad del XVI a $1835^{*}$
}

\author{
Pegerto SaAvedra \\ Universidade de Santiago de Compostela \\ pegerto.saavedra@usc.es
}

\section{Resumen:}

Hasta la década de 1830 , en que tuvo lugar la exclaustración de los regulares y la desamortización en Galicia existían poderosos monasterios benitos y cistercienses, fundados en los siglos centrales de la Edad Media y reformados entre 1490 y 1550 , cuando fueron obligados a incorporarse a las congregaciones castellanas. Sus extensos y dispersos patrimonios rústicos los explotaban mediante cesiones de larga duración foros, a menudo estipulados por una renta fija en especie, aunque también los hubo por cuotas proporcionales a la cosecha. En este trabajo se analizan, a partir de libros de cuentas, apeos y tumbos pertenecientes principalmente a las comunidades del Císter, los problemas relaciones con el control de un patrimonio parcelado y amenazado por la «malicia» campesina y la evolución de la rentas monásticas, comparando su trayectoria y composición los cambios habidos en el sistema agrario, muy importantes desde que a mediados del XVIII se difunde el maíz.

\section{Palabras clave:}

Monasterios; Patrimonios rústicos; Foros; Rentas; Cambios agrarios; Siglos XVI-XIX; Galicia.

\section{Abstract:}

Until the decade of 1830, when the secularization of the regulars and the ecclesiastical confiscation (desamortización) in Galicia took place, there were powerful Benedictine and Cistercian monasteries, founded in the central centuries of the Middle Ages and reformed between 1490 and 1550, when they were forced to join the congregations of Castile. They exploited their extensive and scattered rustic estates through long-term disposals, emphyteusis, often set on a fixed rent in kind, although there also were those based on quota proportional to the harvest. In this paper are analyzed, from books of accounts, landmarks and property records belonging mainly to Cistercian communities, the problems related to the control of assets, parcelled and threatened by the peasant «malice», and the evolution of the monastic rents, comparing their growth and composition with the changes in the agricultural system, very important since, in the middle of the 18th century, corn spreads.

Keywords:

Monasteries; Rustic assets; Contracts; Rents; Agricultural changes; 16th-19th centuries; Galicia.

* Trabajo realizado en el marco del Proyecto de Investigación HAR2009-13304/HIST, "Parroquia y comunidad rural en Galicia, c. 1450-c. 2000", financiado por la Secretaría de Estado de Investigación del Ministerio de Ciencia e Innovación. 


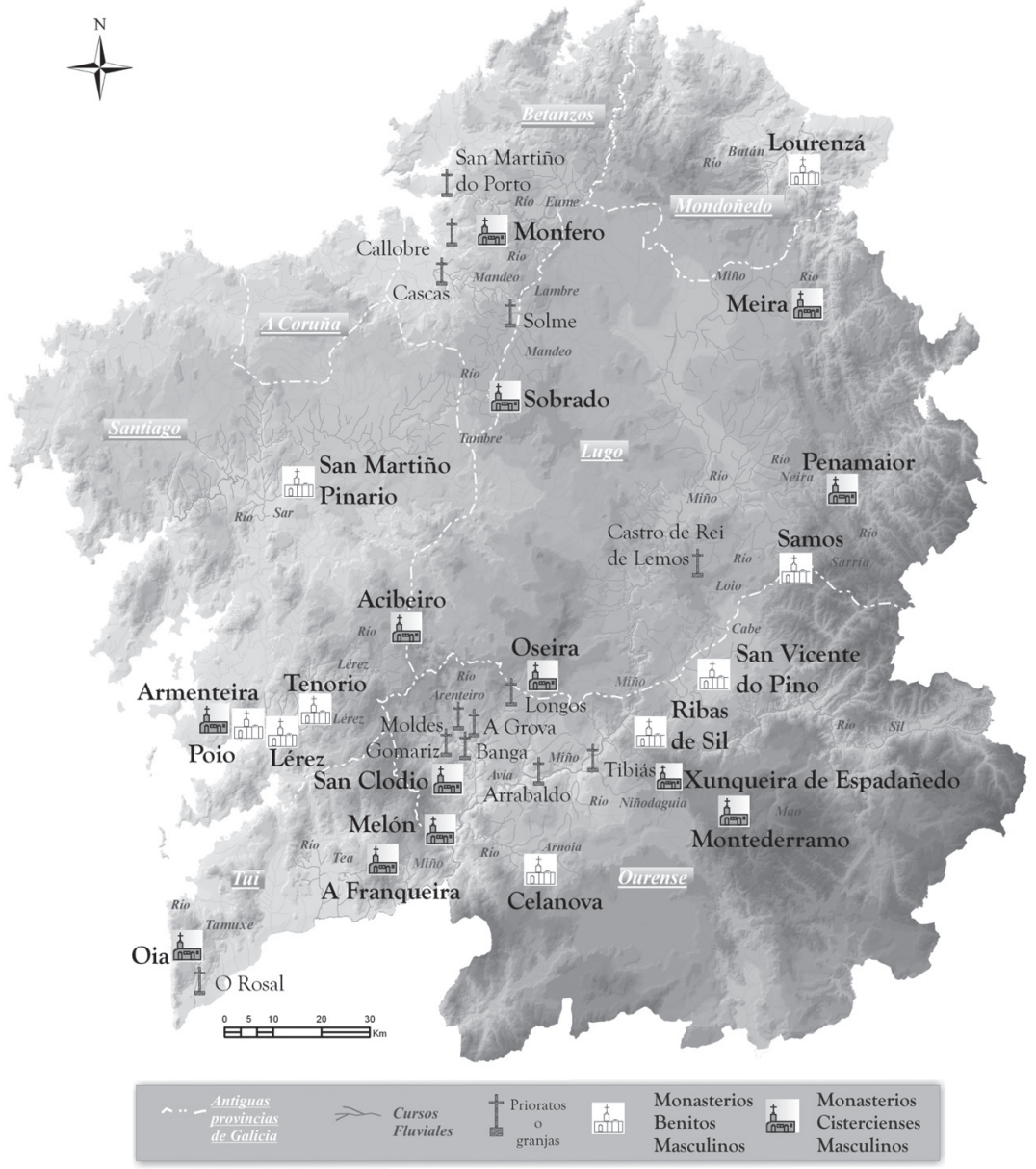




\section{Introducción}

Galicia es un país pequeño, pero con grandes diversidades internas. En sus $29.500 \mathrm{~km}^{2}$ de superficie -un tercio escaso de Portugal-, encontramos comarcas de clima suave, que se extienden a lo largo de los casi $1.900 \mathrm{~km}$ de costa y penetran hacia el interior a través de los valles fluviales abrigados, algunos de los cuales ya presentan ciertas características mediterráneas. Los cereales de invierno y primavera, la vid, los cítricos y en ocasiones los olivos se cultivan o cultivaron en esas tierras situadas a menos de $400 \mathrm{~m}$. de altitud. Pero en el interior áspero y en ocasiones montañoso, la economía campesina se basaba en el cultivo del centeno y en la cría de una abundante ganadería bovina, ovina y caprina. El complejo agropecuario, que notó profundas y a la vez diferentes transformaciones en el curso de la Edad Moderna, reflejaba bien esos fuertes contrastes internos, y más en una época en la que la agricultura era, en atinadas palabras del gran experto en sociología rural Henri Mendrás, "el arte de la localidad". Así, a mediados del siglo XVIII el sistema agrario vigente en el Bajo Miño tenía un "virtuosismo" que lo asemejaba a la jardinería, mientras en las montañas septentrionales los campesinos vivían de cultivar centeno avenoso en régimen de año y vez y de criar ganado en libertad ${ }^{1}$.

Los datos del catastro de Ensenada referidos a cada una de las siete provincias del Reino de Galicia constituyen un buen indicador de las diferencias existentes en 1749-53 en lo tocante al tamaño de las explotaciones, productividad de la tierra, composición y niveles de la cabaña ganadera y densidades de población. No cabe duda de que el catastro, como fuente fiscal, adolece de múltiples ocultaciones, acentuadas en Galicia por la estructura del terrazgo y por la distancia cultural entre las comunidades campesinas y los oficiales encargados de las averiguaciones, pero los datos finales no carecen de coherencia:

1 Como obra fundamental, que ahorra muchas otras citas, vid., Abel Bouhier, Galicia: ensaio xeográfico de análise e interpretación dun vello complexo agrario, Santiago de Compostela, Xunta de Galicia, 2001, 2 vols., y mapas fuera del texto (1 $1^{\text {a }}$ ed. en francés de 1979). 
Cuadro - Densidades de población y variables agropecuarias a mediados del siglo XVIII

\begin{tabular}{|c|c|c|c|c|c|c|c|}
\hline Provincia & $\mathrm{Hbs} / \mathrm{Km}^{2}$ & $\begin{array}{l}\text { Tamaño } \\
\text { medio de la } \\
\text { explotación, } \\
\text { en ha }\end{array}$ & $\begin{array}{l}\text { Núm. } \\
\text { explota- } \\
\text { ciones por } \\
\mathrm{km}^{2}\end{array}$ & $\begin{array}{c}\text { Rendimientos } \\
\text { Hls/Ha } \\
\text { labradío }\end{array}$ & $\begin{array}{c}\text { Cabezas } \\
\text { vacuno por } \\
\text { explotación }\end{array}$ & $\begin{array}{l}\text { Id. de } \\
\text { ovino y } \\
\text { caprino }\end{array}$ & $\begin{array}{c}\text { \% de tierra } \\
\text { cultivada } \\
\text { sobre } \\
\text { superficie } \\
\text { total }\end{array}$ \\
\hline Santiago & 59,4 & 1,22 & 12,4 & $13(259)^{*}$ & 2,94 & 10,52 & 15,2 \\
\hline Ourense & $38,-$ & 1,85 & 7,3 & $8(197)^{*}$ & 2,67 & 8,55 & 14,2 \\
\hline Lugo & 27,5 & 2,31 & 4,5 & $6,1(119)^{*}$ & 5,44 & 15,52 & 11,5 \\
\hline Betanzos & 39,8 & 1,44 & 7,5 & $15,5(342)^{*}$ & 4,84 & 9,56 & 11,6 \\
\hline Mondoñedo & 38,7 & 1,36 & 7,5 & $14(299)^{*}$ & 4,23 & 7,27 & 10,9 \\
\hline Tui & $100,-$ & 0,56 & 21,8 & $18,5(418)^{*}$ & 1,71 & 3,91 & 12,5 \\
\hline A Coruña & 53 & 1,7 & 8,2 & $19,7(398)^{*}$ & 4,39 & 15,32 & 14,1 \\
\hline Galicia & 44,1 & 1,56 & 8,56 & $10,75(234,5)^{*}$ & 3,64 & 10,47 & 13,4 \\
\hline
\end{tabular}

* Entre paréntesis: rendimientos en reales/ha. Algunas discordancias que se observan entre rendimientos en hls/ha y rs/ha derivan de las diferencias comarcales de precios, de acuerdo con las declaraciones de los vecinos, y que conocemos por el trabajo de Angel I. Fernández González, "El Catastro de Ensenada como fuente para la Historia Económica: la cuestión de los precios", VI Congreso de la Asociación Española de Historia Económica, Gerona, 1997, Preactas, pp. 61-69.

Fuente: Elaboración a partir del Archivo General de Simancas, Dirección General de Rentas, $1^{\text {a Remesa, }}$ leg. 1.977 .

Puede advertirse que las densidades de población oscilan de 27,5 a 100 hbs/ $/ \mathrm{Km}^{2}$, los rendimientos de 6,1 a 19,7 hls/ha, el tamaño medio de las explotaciones de 0,56 a 2,31 ha, las cabezas de vacuno por explotación de 1,71 a 5,44, y las de ovino y caprino de 3,91 a 15,52. Las cifras medias de cada provincia esconden a la vez diversidades internas, y si fuese posible descender a matices comarcales los contrastes serían aun más fuertes ${ }^{2}$. En todo caso, Lugo y Tui son las provincias más diferentes: en la primera domina una rotación de año y vez, a base de centeno; en consecuencia las explotaciones han de tener cierta extensión, y están bien dotadas de ganado vacuno, ovino y caprino, alimentado total o parcialmente en los dilatados montes comunales. En Tui las rotaciones son intensivas, con el maíz como cereal dominante, las explotaciones minúsculas y con poco ganado, si bien la densidad de bovinos por ha total o cultivada es superior a Lugo, porque en la provincia del Miño hay 21,8 explotaciones por $\mathrm{km}^{2}$ frente a sólo 4,5 en Lugo. En las tierras tudenses la cabaña vacuna -vacas

2 Así, algunos valles de la provincia de Ourense tienen en el siglo XVIII densidades semejantes a las de Tui, y en comarcas como Celanova la agricultura era muy intensiva. Vid. Delfina Rodríguez Fernández, A terra e as xentes. Nacer, vivir e morrer na comarca de Celanova ó longo da Idade Moderna, A Coruña, Vía Láctea Editorial, 1999, pp. 37 y ss. Abundante información sobre la distribución de la población en 1787 en Antonio Eiras Roel, La población de Galicia, 1700-1860, Santiago de Compostela, Fundación Caixagalicia, 1996, pp. 157 y ss. 
y crías- se sostenía con forrajes obtenidos en la explotación (nabos, centeno en verde, hierba cultivada entre el maíz y caña de este cereal), pues apenas hay prados. Los campesinos se las ingeniaron para alimentar de modo "moderno" la cabaña vacuna, de ahí que se censen en 1750 unas 220 cabezas por ha de prado. El monte estaba subordinado a usos agrarios y servía sobre todo para producir tojo para abono; a tal fin se privatizaran ya hacia 1750 muchas parcelas de comunal ${ }^{3}$.

Pero por encima de las diferencias comentadas, y de otras dejadas a un lado, había también rasgos comunes que quedan de manifiesto en algunas de las variables expuestas en el cuadro. Uno de ellos consiste en el predominio de la pequeña explotación familiar, llevada a menudo en régimen de foro (o de arriendo en la Galicia cantábrica); otro, en que sólo se cultivaba de modo permanente una parte reducida de la superficie total: el 13,4 por cien de promedio de acuerdo con los datos del catastro ensenadino. Sin duda esta cifra ha de elevarse un poco, pero aunque se aumentasen en un 50 por cien los ferrados de labradío, prado, viña y soto declarados, no representarían una quinta parte de la extensión del Reino. Esta era la proporción de tierra cultivada que calculaba hacia 1800 José Lucas Labrada, después de advertir que en las últimas décadas del XVIII se había registrado un intenso proceso de roturaciones, que acreditan bien los protocolos y las fuentes judiciales ${ }^{4}$.

La mayor parte de la tierra de aldeas y parroquias estaba, por tanto, constituida por montes, un espacio en el que se obtenían recursos muy variados, de desigual importancia para las familias campesinas: leña, carbón, madera,

3 Cf. José Manuel Pérez García, "En los límites del virtuosismo agrario tradicional: la fertilidad de la comarca del Bajo Miño (1730-1860)", Ler História, 36 (1999), pp. 221-224, y del mismo autor, "Entre regar y no regar: la intensa disputa por unos recursos hídricos colectivos escasos en la Galicia Meridional (1600-1850)", en Francisco José Aranda Pérez, coord., El mundo rural en la España moderna, Cuenca, Universidad de Castilla-La Mancha, 2005, pp. 557 y ss., y "Las utilidades del inculto y la lucha por sus aprovechamientos en la Galicia Meridional (1650-1850)", Obradoiro de Historia Moderna, 9 (2000), pp. 79-107. También Pegerto Saavedra, "El agua en el sistema agropecuario de Galicia", en Alberto Marcos Martín (coord.), Agua y sociedad en la época moderna, Universidad de Valladolid, 2009, pp. 49 y ss.

4 José Lucas Labrada en su Descripción económica del Reino de Galicia, publicada en 1804, en Ferrol, afirmaba que "cuando menos el tercio de las tierras que hoy están cultivadas se debe a los rompimientos que se han hecho de las que estaban incultas hace unos cincuenta años” (p. 199 de la edición de 1971, Vigo, Galaxia, a cargo de Francisco Río Barja). Sobre las ocultaciones del catastro de Ensenada, José Manuel Pérez García, "Fuentes de control de los catastros fiscales: las escrituras de protocolos", en Actas de las I Jornadas de Metodología Histórica Aplicada a las Ciencias Sociales, Universidad de Santiago de Compostela, 1975, vol. III, pp. 203-212, y, del mismo, "Un chequeo al catastro del Marqués de Ensenada en la comarca del Bajo Miño", Cuadernos Feijonianos de Historia Moderna, I (1999), pp. 153-192. 
piedra, pastos, cosechas de centeno y trigo en las rozas, "estrumen" para abonar las tierras, caza y frutos silvestres utilizados como alimento... En el catastro de Ensenada los vecinos reputaron de "inútiles por naturaleza" o improductivos una enorme extensión de montes; se trata de una estrategia para defraudar, que no debe ocultar que escasos eran los espacios comunales que no proporcionaban algún recurso y que, a fin de cuentas, entre bravo y manso no existía oposición o separación, sino unión inextricable, pues gracias al monte funcionaban y se reproducían las explotaciones campesinas, de ahí la necesidad de mantener, en especial en las comarcas de agricultura más intensiva, con muchas necesidades de abono, una correlación entre superficie cultiva e inculta, al estar ésta última subordinada a usos agrarios ${ }^{5}$.

Si con un porcentaje de tierra cultivada que de promedio no llegaba en 1750 a una quinta parte de la superficie total, Galicia alcanzaba sin embargo elevadas densidades de población, ello se debe a que los campesinos conseguían notables rendimientos en sus pequeñas explotaciones. De acuerdo con los datos del catastro de Ensenada, la media de familias o vecinos por ha cultivada era de 0,74, con un máximo de 1,79 en Tui y un mínimo de 0,43 en Lugo, y la de habitantes en 3, con máximos y mínimos de 7,14 y 2,38, en las mismas circunscripciones. Claro que a la sazón muchas familias tenían ocupaciones complementarias, que diversificaban sus fuentes de ingresos: la industria textil rural (en especial la fabricación de lienzos), la emigración por unos meses o por varios años a ambas Castillas, Andalucía y Portugal, el desempeño de oficios especializados en la cantería, la siderurgia, la alfarería, los curtidos o el transporte constituían actividades más o menos extendidas por el Reino, no siempre visibles en las fuentes (propincuas a ocultar el trabajo femenino, por ejemplo en el sector textil), y sin duda decisivas para la obtención de los recursos monetarios imprescindibles para comprar ropas, herramientas, menaje y alimentos, y para pagar no solo las cargas a la hacienda real -más bien escasas-, sino también las rentas forales fijadas en especie, pero satisfechas en parte en dinero, toda vez que el campesino necesitaba el centeno, trigo, maíz o mijo para el consumo y la siembra ${ }^{6}$.

5 Fue sin duda Abel Bouhier en su Galicia, vol. II, pp. 755 y ss., quien mejor entendió el papel del monte en la agricultura tradicional gallega. Vid., también, Xesús Balboa, $O$ monte en Galicia, Vigo, Xerais, 1990 (analiza en detalle el creciente uso agrario del monte); Pegerto Saavedra, Das casas de morada ó monte comunal, Santiago de Compostela, Xunta de Galicia, 1996, pp. 331 y ss.; y Ofelia Rey Castelao, Montes y política forestal en Galicia, Universidad de Santiago de Compostela, 1996.

6 Sobre las actividades complementarias o "pluriactividad campesina", Xoán Carmona, El atraso industrial de Galicia, 1750-1950. Auge y liquidación de las manufacturas textiles, 
Y es que la presión de la renta foral tendió a convertirse en un importante factor -aunque no en el único- que obligaba a las pequeñas explotaciones a relacionarse en el mercado, bien fuese de productos, de mano de obra o de crédito. Lo exponía con claridad hacia 1800 el canónigo compostelano Pedro Antonio Sánchez, admirador de Adam Smith, en varios pasajes de sus diversos escritos. Por ejemplo, cuando afirmaba que las ventas de vacuno proporcionaban a los labradores los recursos monetarios para sus cotidianas urgencias: "No tiene granos suficientes para pagar las pensiones cargadas sobre las tierras: su auxilio es el ganado"; o cuando se refería a las causas de las salidas a las siegas de Castilla: "De ahí el que en aquellos meses en que falta el pan, se van en tropas a Castilla, no menos por alimentarse que por ganar la paga de la renta del propietario" . A la misma práctica aludía en mayo de 1793 un mayordomo que el conde de Amarante tenía en la ría de Arousa, para explicar las dificultades que encontraba para cobrar las rentas atrasadas: "los más de los caseros se lamentan de lo crítico de la estación para pagar deudas, porque en este tiempo no tienen un cuarto, hasta agosto que venden cuatro ferrados de trigo (...). En la actualidad van muchos en Castilla, y principalmente en junio casi todos, y no vuelven hasta el agosto, a cuyo tiempo (...) podrán exigirles las rentas del 91 y 92, pues entonces además del trigo tienen algún dinero y les es menos sensible el afronto" ${ }^{8}$. Los contemporáneos veían en las exportaciones de vacuno y de mano de obra las fuentes de ingresos monetarias de las familias campesinas, con los que podían satisfacer en dinero una parte de las rentas estipuladas en especie, aunque la pluriactividad campesina revestía formas muy variadas.

\section{Rentas forales y cultivos}

La estructura agropecuaria vigente a mediados del XVIII era el resultado de una evolución que no se había iniciado, pero sí acelerado en el curso del XVII, a raíz principalmente de la llegada y difusión del maíz. Los cambios que desencadenó en las comarcas litorales y valles fluviales la gramínea americana no afectaron sólo a los cereales tradicionales, a las rotaciones y rendimientos, sino también a los niveles y composición de la cabaña ganadera, a los usos

Barcelona, Ariel, 1990, y Aurora Artiaga y Angel Fernández González, “Labradores, gandeiros, artesáns e traficantes: unha aproximación ás actividades productivas da poboación rural en Galicia, 1750-1900", Sémata. Revista de Humanidades e Ciencias Sociais, 9 (1998), pp. 307-341.

7 Pedro Antonio Sánchez, La economía en los escritos de..., ed. de Xosé Manuel Beiras, Vigo, Galaxia, 1973, pp. 119 y 259.

8 Archivo de la Fundación Ducal de Medinaceli (Sevilla), Fondo Camarasa, secc. Amarante, Correspondencia, leg. 92, sin foliar. 
del monte y al tamaño de las explotaciones. Todo el complejo tecnológico agropecuario se vio transformado, dada la interdependencia de las diversas variables. Algunos cambios tienen carácter opaco, caso de la extensión de plantas forrajeras o del creciente uso agrario del monte; otros quedan mejor reflejados en las fuentes, en especial los tocantes a la tendencia y estructura de la producción cerealera ${ }^{9}$. Este será el tema central de las páginas que siguen, en las que se abordan no sólo las mundanzas en los cultivos sino los efectos que éstas tuvieron en los ingresos de diversas comunidades monásticas.

Para nuestro propósito las mejores fuentes son las pertenecientes a los monasterios del Císter, aunque también tienen interés los "estados cuatrienales" de los monjes benitos, conservados sólo para las décadas de 1780 y $1820^{10}$. Hasta la exclaustración de 1835 existían en Galicia trece comunidades cistercienses, que se habían fundado o afiliado a la orden -menos la de Penamaior, todas la rama de Clairvaux- desde 1140 a mediados del siglo XIV ${ }^{11}$. Las había muy poderosas, como Sobrado y Oseira, que por el volumen de rentas y por el número de monjes que sostenían -cerca de un centenar a mediados del XVIII, contando los "granjeros" destacados en los prioratos- se hallaban entre las más ricas de la congregación de Castilla -aunque estén por detrás del gran monasterio de Alcobaça-; otras de tipo mediano, caso de Montederramo, Melón, San Clodio, Oia o Monfero, y no faltaban las modestas o pequeñas, como Armenteira, Penamaior, Acibeiro y sobre todo A Franqueira, que no solía contar con más de cinco monjes. Las tres últimas no eran casas matrices o abadías, sino simples "presidencias", gobernadas directamente por el abad del monasterio de Palazuelos, sede de la congregación de Castilla ${ }^{12}$.

9 Una exposición de los diversos cambios y de su interrelación en Pegerto Saavedra, "Petite exploitation et changement agricole à l'intérieur d'un «vieux complexe agraire». Les campagnes de la Galice entre 1550 et 1850”, Histoire et Sociétés Rurales, 12 (1999), pp. 63-108.

${ }^{10}$ Vid. Camilo Fernández Cortizo, "Los «estados» cuatrienales y la economía de los monasterios benedictinos gallegos en la época moderna”, en José Manuel López Vázquez, coord., Opus monasticorum. Patrimonio, Arte, Historia y Orden, Santiago de Compostela, Xunta de Galicia, 2005, pp. 63-95.

${ }^{11}$ Vid. Ermelindo Portela Silva, La colonización cisterciense en Galicia: (1142-1250), Universidad de Santiago de Compostela, 1981, y Fray Mํ Damián Yáñez Neira, Monasticón cisterciense gallego, Vigo, Caixavigo e Ourense, 2000, 2 vols. El proceso de afiliación o fundación está casi concluido en 1225 , pues a partir de ese año sólo se unen a la orden los pequeños cenobios de A Franqueira y Acibeiro.

${ }^{12}$ Enrique Martín, Los bernardos españoles (Historia de la Congregación de Castilla de la orden del Císter), Palencia, Gráficas Aguado, 1953. 
Una relación de 1803, que contiene inexactitudes -en particular en el capítulo de ingresos-, permite clasificar a los monasterios de acuerdo con el número de monjes que sustentaban a la sazón y con su volumen de ingresos en numerario.

Cuadro - Los monasterios bernardos gallegos en 1803 : número de monjes e ingresos monetarios

\begin{tabular}{lccc}
\hline \multicolumn{1}{c}{ Monasterio } & Núm. monjes & Ingresos, rs. & \\
\hline Oseira & 80 & 352.193 & $(323.704)^{*}$ \\
Sobrado & 76 & 300.000 & $(325.566)^{*}$ \\
Montederramo & 52 & 163.505 & $(213.827)^{*}$ \\
Melón & 43 & 143.000 & $(?)$ \\
Meira & 42 & 132.000 & $(?)$ \\
Monfero & 41 & 119.150 & $(154.139,5)^{*}$ \\
San Clodio & 30 & 110.000 & $(119.091)^{*}$ \\
Oia & 26 & 96.553 & $(143.886)^{*}$ \\
Armenteira & 26 & 80.000 & $(90.797)^{*}$ \\
Acibeiro & 20 & 102.730 & $(?)$ \\
Xunqueira de Espadañedo & 10 & 50.217 & $(49.859)^{*}$ \\
Penamaior & 7 & 65.367 & $(?)$ \\
A Franqueira & 5 & 22.173 & $(21.154)^{*}$ \\
\hline
\end{tabular}

* Ingresos que figuran en los libros de caja o estado, consultados por nosotros. En Montederramo la cantidad de 1803 se ha dividido por 2, pues incluye la del año anterior. De Melón, Meira, Acibeiro y Penamaior no conseguimos datos directos de contabilidades.

Fuente: Luis Fernández Martín, "Estado espiritual y temporal de los monasterios bernardos de Galicia en vísperas de la Guerra de la Independencia. 1803”, Hispania Sacra, 44 (1992), p. 411.

A la sazón, el número de monjes ya comenzaba a descender y los ingresos en numerario, medidos en valores reales, también, por algunos impagos y por el aumento de la fiscalidad real (que exige el noveno decimal desde comienzos del XIX, aparte de "donativos"), pero hasta la Guerra de la Independencia los monasterios no sufrieron graves dificultades, ni después su situación puede compararse a la que atraviesan las comunidades regulares del centro y sur peninsular, en donde hubo una primera exclaustración en 1808 -desconocida en Galicia-, cuyos efectos se agravaron al tener parte del patrimonio en explotación directa (sus cabañas ganaderas fueron sacrificadas o robadas, los inmuebles deteriorados) y al existir una mayor oposición social a los estamentos privilegiados. Significativo al respecto resulta que en 1815-16 los capítulos generales de la congregación de Castilla (Císter) y de los benitos se celebrasen, respectivamente, en los monasterios orensanos de Oseira y Celanova, por el estado ruinoso de las instituciones cabezas de cada congregación, radicadas en Valladolid (San Benito de Valladolid y Palazuelos) ${ }^{13}$.

${ }^{13}$ Pegerto Saavedra, "Economías cistercienses del Antiguo Régimen: el Imperial monasterio de Oseira", en Modernitas. Estudios en homenaje al profesor Baudilio Barreiro Mallón, 
Los ingresos en numerario de los monasterios son indicativos de su capacidad financiera, pero no representan la totalidad de las entradas, fijadas en su mayor parte en especie, y parcialmente gastadas en empleos varios (alimentación, limosnas). Las rentas en dinero son fruto de la venta de los cereales y vino no consumidos y en consecuencia son ingresos parciales, aunque para los gestores monásticos el "recibo" en numerario constituía el indicador decisivo de la capacidad económica de la institución, sobre todo porque le permitía acometer obras y pleitos; de ahí la importancia de los precios agrarios, que elevaban o reducían el recibo y facilitaban o entorpecían los proyectos de los abades ${ }^{14}$.

$\mathrm{Si}$ se atiende a las rentas globales percibidas en especie se observa que cerca de tres cuartas partes correspondían a foros estipulados con frecuencia por tres voces o generaciones, y según avanzaba el XVII por tres vidas de reyes $-\mathrm{y}$ convertidos en la práctica en perpetuos por real provisión de 11 de mayo de 1763-; el resto procedía de los diezmos y, en mucha menor medida, de "servicios" satisfechos en concepto de señorío ${ }^{15}$. Y aunque en la Edad Moderna la práctica dominante era estipular foros por una renta fija en especie, en la

Universidade de A Coruña, 2008, pp. 161-190, y, del mismo, "Les senyories monàstiques a la Galícia moderna”, Afers. Fulls de recerca i pensament, 65 (2010), pp. 113-141.

${ }^{14}$ Esta realidad queda de manifiesto en los abadologios, para cuyos autores el "recibo" fundamental es el de dinero, y depende básicamente de los precios. El autor de uno de Oseira señala, por ejemplo, a propósito del abad don fray Eugenio de Barros (1717-1721), que "no pudo hacer muchas obras porque no tuvo medios para ellas, por valer en todo su tiempo muy baratos los frutos del monasterio"; algo parecido le sucedió a don fray Cristóbal de Posadilla (1741-1744): "En su trienio estuvieron todos los frutos a precio ínfimo, por la abundancia que de ellos hubo, pues llegó a darse en cuentas por moyo de vino a quince reales y por fanega de centeno a diez, y por lo mismo el recibo fue corto". En Miguel Romaní Martínez, director, El «Memorial» de Oseira en el códice 15-B del AHN. Aportaciones a la Historia, Arte y Patrimonio del monasterio (1486-1828), Santiago de Compostela, Andavira Editora, 2009, pp. 41 y 47. También en 1742 el abad de San Martiño Pinario de Santiago (el monasterio con mayores rentas de Galicia), hacía unas reflexiones parecidas, vinculando el ritmo de las obras con el nivel de los precios agrarios: "si suben mucho [los precios], como ha sucedido algunos años, sobra algo [de dinero], y en este caso el superesse se emplea cuasi en limosnas; pues verdaderamente lo son dar que hacer a muchos oficiales en las obras precisas que faltan a este monasterio, como es un claustro principal que no tiene, y hace 108 años que se comenzó, sin que hasta ahora se haya podido acabar por falta de medios (...). Sólo cuando los frutos están en mayor estimación podrá el monasterio cumplir con todos los gastos (...), pagar sus empeños y proseguir las obras mayores"; en Ramón Villares, "La economía del clero regular gallego ante la desamortización", Cuadernos de Estudios Gallegos, XXXII (1981), p. 106.

${ }^{15}$ Angel Fernández González, "A Igrexa como institución rendista ó longo do Antigo Réxime”, en O Feito Diferencial Galego. I. Historia, Santiago de Compostela, Museo do Pobo Galego, 1997, vol. 2, pp.58-73, en donde analiza la naturaleza jurídica de los ingresos del clero regular y secular. 
Galicia occidental y en las comarcas vitícolas de Ourense no fueron infrecuentes las rentas proporcionales a la cosecha. Las ventajas e inconvenientes de unas y otras rentas no les pasaban desapercibidos a los monjes encargados de administrar los prioratos, alguna oficina monástica o de realizar apeos. En la Edad Media los foros proporcionales fueron muy corrientes, lo que significa que la capacidad de control de los monasterios, la inmediatez del poder señorial en definitiva, era muy elevada. En la Edad Moderna se impuso la opción por las rentas fijas, debido tal vez a que la reforma monástica de 1490/1550 -implantación de la observancia- obligaba a los religiosos, en principio, a una clausura más severa, y a que la supresión de muchos pequeños cenobios y la agregación de su patrimonio a otros, en la condición de prioratos, hizo que los monasterios subsistentes, en particular los principales, viesen muy agrandados, y a la vez dispersando el patrimonio ${ }^{16}$. Desde mediados del XVI la congregación cisterciense permitió que hubiese monjes "granjeros" en los prioratos, pero ello no supuso el retorno a los foros proporcionales.

A diferencia de lo que sucedió con los cistercienses del valle del Duero, y en menor medida con los del Reino de Aragón, los de Galicia, al igual que los del norte de Portugal, no parecen haberse planteado en ningún momento de la Edad Moderna explotar directamente la parte sustancial del patrimonio ${ }^{17}$.

${ }^{16}$ Ramón Villares, Foros, frades e fidalgos, Vigo, Xerais, 1982, del mismo, "Los foros de Galicia. Algunos problemas y comparaciones (Galicia, Portugal, Valencia)", Ler História, 12 (1988), pp. 47-75, y Ramón Villares y José Luis Díaz-Castroverde, O conflicto foral nos séculos XVII e XVIII, Ourense, Xunta de Galicia/Caixa Ourense, 1997.

${ }^{17}$ Fuera de la tierra incluida en la cerca monástica, y de la explotación anexa a cada priorato (sobre todo en comarcas vitícolas), la explotación directa parece desconocida. Para el caso portugués, vid., José Marques, "Os mosteiros cistercienses nos finais do século XVIII", en Actas. Congreso Internacional sobre San Bernardo e o Císter en Galicia e Portugal (Ourense), Zamora, Ediciones Montecasino, 1992, vol. I, pp. 649-675. Este autor dirigió en la Universidad de Porto una serie de investigaciones sobre monasterios; cfr., en especial, Salvador Magalhães Mota, Cistercienses, camponeses e economia rural na época do Antigo Regime. O mosteiro de Santa Maria de Bouro e o seu dominio, Lisboa, Imprensa Nacional-Casa da Moeda, 2006; e Fernanda Paula Sousa Maria, O mosteiro de Bustelo: propiedade e produçao agricola no Antigo Regime (1638-1670 e 1710-1821), Porto, Universidade Portucalense, 1991. Hay que mencionar también el estudio ya clásico de Aurélio de Araújo Oliveira, A abadia de Tibães: 1630/80-1813: propiedade, exploraçao e produçao agricolas no vale do Cabado durante o Antigo Regimen, Porto, Facultade de Letras, 1979, 2 vols. Un ejemplo de monasterio cisterciense del valle del Duero que explota de modo directo la mitad de su patrimonio, desde comienzos del XVII, lo constituye la comunidad de la Santa Espina, de Valladolid; vid. José Miguel López García, La transición del feudalismo al capitalismo en un señorío monástico castellano: el abadengo de la Santa Espina (1147-1835), Valladolid, Junta de Castilla y León, 1990. En Andalucía, los cartujos y jesuitas se inclinaron, hasta las turbulencias de 1808, por la explotación directa, muy criticada por los ilustrados, que los acusaban de dedicarse a "granjerías". 
A fines del XVI y en el XVII, las discusiones y "pareceres" de los que hay constancia en los libros de administración giran alrededor de si son preferibles los foros proporcionales o fijos, si conviene cobrar directamente -por medio de un "granjero"- las rentas o resulta mejor arrendarlas en pública subasta -como solían hacer los cabildos catedralicios, las mitras y la nobleza cortesana-, o-pocas veces- si conviene dar el dinero a censo, invertirlo en juros, alcabalas o hacienda raíz.

En relación con lo último, hay que recordar que el patrimonio fundamental de los regulares consistía en tierras cedidas en foro, y en consecuencia no se muestran proclives a las inversiones en rentas reales como alcabalas o juros, aunque a veces se vean forzados a ello. Tocante a esto, hacia 1608 un monje de San Clodio aconsejaba conservar la hacienda raíz y no aventurarse a realizar desembolsos para adquirir alcabalas que vendía el monarca. A la vista de la crisis financiera de 2008-2011, cabe admitir que las reflexiones del monje cisterciense no han perdido actualidad: "En esto [si es más útil conservar tierras y rentas que venderlas e invertir en juros y censos], hombres graves y doctos de nuestra Congregación y de otras, y todos los que tratan de perpetuar sus bienes, así los eclesiásticos como los seglares, lo tienen por llano y sin duda, porque es mucho mejor hacienda la de la propiedad que la de los juros y censos, porque aquella quebrará con mucha dificultad (aunque a veces sube y baja con los tiempos), y los juros y censos se ven cada día quiebras en ellos, y se puede tener alguna gran quiebra, según andan los tiempos"18.

En lo tocante a la opción por las rentas fijas o proporcionales, el monje que a comienzos del XVII elaboraba el "tumbo viejo" de Oia advertía: "En todas casas de este mundo hay opiniones, y así también en esto las hay". Reconoce que la renta sabida "se cobra sin trabajo y zozobras, trayéndola a casa sin gasto", pero él prefiere las "raciones" o parte de frutos, y cita en abono de su opción que el monasterio de San Clodio tenía rentas muy elevadas en el Ribeiro, gracias a los quintos y sextos del vino, en tanto del de Melón cobraba de rentas fijas unos 50 moyos, que ascenderían a 300 si los foros se estipulasen al sexto. La renta fija daba ocasiones, además, a que los foreros pagasen con el vino de peor calidad -a veces comprado al efecto-, quedándose ellos con el bueno, algo que también denunciaba un religioso de Meira ${ }^{19}$.

Sin embargo, a los monjes de San Clodio de Leiro los foros proporcionales no dejaban de crearles problemas, por la tendencia de los campesinos a ocultar

${ }^{18}$ Archivo Histórico Nacional (Madrid), Clero. Códices y Cartelarios. Códice 424 de San Clodio, f. 656.

${ }^{19}$ Archivo Histórico Nacional (Madrid), Clero, libro 10.181 de Oia. 
las parcelas de dominio del monasterio, y en consecuencia a dejar de contribuir con la correspondiente cuota de frutos, pues, como se infiere con facilidad, si no identificaba la tierra, el rentista no podía exigir quintos o sextos. Hacia 1616 el monje encargado de la realización de un tumbo se quejaba de las dificultades, a veces insuperables, que encontraba en las diversas granjas, por los enredos, embustes, mandas, divisiones, ventas y negaciones de dominio: "porque aunque hoy se haga un fuero [foro] de cuatro viñas a uno, mañana lo tiene todo dividido, enajenado y ocultado, y no aguardan a sus hijos [o segunda voz] para negarlo, sino que los mesmos que [en] un apeo confiesan, mañana lo venden como propio diezmo a Dios y si viene otro apeo lo ocultan y pasan en silencio con grandísima facilidad". En esta tierra, insiste, "he hallado por experiencia hay mucha facilidad en negar la hacienda que es del monasterio, haciéndola diezmo a Dios y, dado caso que no lo hagan muchos no pagan bien (...), y ansí hay grandísima necesidad de poner remedio en esto y no sé cuál pueda ser"; señala para probar los fraudes que, por controles realizados para pagar la sisa del vino, en algunas partes el monasterio sólo cobra lo equivalente al diezmo, pero no los quintos y $\operatorname{sextos}^{20}$. Estas advertencias iban acompañadas de modelos de escrituras de foros -con cláusulas orientadas a evitar ocultaciones y fraudes-y de consejos sobre la conveniencia de controlar la sucesión de voces: "hay grandísima necesidad de nombrar las voces" -lo que apenas se hace-, "y ansí quieren hacer los foros perpetuos, y aunque vaguen [vaquen] no hacen caso de hacer foro de nuevo, sino llevarlo como se les antoja" $"$.

En todo caso, San Clodio mantuvo los foros proporcionales en una parte importante de su dominio. Al componerse éste de tierras destinadas sobre todo a la producción de vino, concentradas en los valles fluviales próximos al cenobio, los religiosos preferían tratar de controlar parcelas y cosechas, y cobrar en el momento de la vendimia -sin atrasos, por tanto-, a percibir cantidades fijas que, en razón de las partijas, acababan repartidas entre multitud de pagadores de

\footnotetext{
${ }^{20}$ Archivo Histórico Nacional (Madrid), Clero, códice 424 de San Clodio. Como para la realización de apeos se requería la declaración de testigos, el monasterio no encontraba -ni tampoco- en los pleitos quién declarase a su favor: si el reconocimiento de la hacienda monástica depende de las declaraciones de los vecinos, "yo doy por perdida la de esta casa", advierte el monje, partidario de exponer a los oidores de la Real Audiencia del Reino lo que sucedía: "pues con todo y de apeos ser la hacienda del monasterio, no es razón que ahora la pierda por maliçia de los que la quieren negar, por no hallar testigos que lo digan, que si en un lugar hay treinta vecinos y los veinte y nueve quieren ocultar cada uno la parte que lleva mal se podrá hacer probanza en favor del monasterio". $I b$.

${ }^{21}$ El control de la sucesión de voces resultaba imprescindible para saber cuando fenecía el foro, y además a veces las rentas cambiaban de una voz a otra, haciéndose más pesadas (por ejemplo la primera voz podía pagar el séptimo, la segunda el sexto y la tercera el quinto).
} 
vecindades diversas. Lo señalaba en 1592 el monje que administraba la granja de Esposende, cuando reparaba en que había cargas fijas que se cobraban al tiempo de la vendimia, asentadas en un memorial: "pero advierto, añade, que jamás se haga foro a vino derretido, porque lo que era diezmo junto cuando se aforó, de allí a veinte años está dividido entre treinta dueños, y uno un canado, otro medio, otro una cuarta; el uno vive en Santiago, el otro en Orense, otro no sé donde, lo cual es grande perdición y se gasta más en cobrar [que] lo que vale; y aforarse a uvas, aunque se divide, cada uno paga cuando vendimia, y lo trae al lagar lo que cabe [a] su quiñón de quinto o sexto. Y más se detiene el religioso en cobrar este poco derretido en Esposende que en toda la vendimia, fuera de haber de tener un hombre que ande quince o veinte días con un cuero yendo veinte veces a buscar medio canado de vino"22.

Dado que la vendimia debía comenzar en la fecha autorizada por los señores o cuando no por las autoridades concejiles, a los monasterios les era relativamente fácil controlar los cestos de uvas que se iban recogiendo, mediante la contrata de algunos "mayordomos" que asistían con el monje granjero a los trabajos y vigilaban a los colonos. San Clodio o San Martiño Pinario, por ejemplo, exigían a cada forero que pidiese licencia para vendimiar, momento que aprovechaban para ver si tenía deudas pendientes y proceder a cobrarlas. El prior que San Martiño de Santiago tenía destacado en Beiro, por ejemplo, advertía que si no se recuperaban los atrasos antes de dar licencia para vendimiar, "después de hecha la vendimia no hay quien les saque el vino de las cubas si no es con muchos enfados y trabajos". Avisaba asimismo de que al final era contraproducente ahorrar en jornales de mayordomos ("diezmeros") o vigilantes, porque el colono tenía irresistible inclinación a "hurtar alguna cantidad de cestos, o [a] no [llenarlos] tan bien para la granja [del monasterio], como para su lagar, o a no dar la uva tan buena, tan madura y sana como lleva para sí, [pero] llevando mayordomo, aunque no lo quiera ha de hacerlo (...) y no se ha de atrever a hurtar tanto" 23 .

${ }^{22}$ En Manuel Lucas Álvarez, "Una aproximación a las superficies y rentas en el patrimonio del monasterio de San Clodio del Ribeiro de Avia (Ourense)", en Humanitas: estudios en homenaxe ó Prof. Dr. Carlos Alonso del Real, Universidade de Santiago de Compostela, 1996, vol. I, p. 473.

${ }^{23}$ En A. I. Fernández González, “A fiscalidade eclesiástica en Galicia, 1750-1850”, Tesis Doctoral inédita, Fac. de Ciencias Económicas, Universidad de Santiago de Compostela, 1995, pp. 608 y ss. El experimentado monje granjero explica que a veces utiliza una argucia para ahorrar en jornales de mayordomos: "y para evitar los gastos de los jornales de los mayordomos hay otro remedio, del cual suelo usar: cuando los foreros vienen a pedir vendimia se les manda traiga cada uno su vendimiador de los extranxeros [forasteros] que ellos alquilan para sus vendimias, y no los paniaguados que tienen en sus casas, y venidos delante del relixioso los trueque desta 
Día tras día, los monjes granjeros habían de enfrentarse a la malicia campesina: "no hay de quien hacer confianza, así de los [foreros] de Ombre y Noguerosa como de los de Socastelo (...); están siempre dispuestos a pegarla; $\mathrm{y}$ es necesario darles mayordomos de ciencia y conciencia, aunque se les pague más de lo que se acostumbra. De suerte que este priorato (...) está en manos de piratas", se quejaba en 1759 el religioso destacado en San Martiño do Porto, sufragáneo de Sobrado, mientras el que en 1688 administraba las rentas de Castro de Rei de Lemos, dependiente de Montederramo, advertía a sus superiores: "con la gente desta tierra es menester ver cómo se trata y habla con ellos, porque es maliciosa sobremanera, y las chanzas las tienen por veras, y quitan el crédito con mucha facilidad, sin atender a lo que dicen, como montañeses, y así encargo que con ellos trate [el futuro "granjero"] lo menos que pudiere, y esto en cosas necesarias, y en particular le encargo que a los vasallos les haga tener cortesía, y que reconozcan el vasallaje, porque de otra suerte se subirán a las barbas y harán lo que quisieren; apretarles para que paguen, porque de otra suerte no se acuerdan"24.

Cuando los monasterios tenían jurisdicción sobre los foreros la capacidad de control y presión aumentaba, como se deduce del texto anterior y de otros muchos, varios de ellos relacionados con la recobración, previo pago de cantidades elevadas a la Hacienda Real, de varios cotos vendidos por Felipe II. Los monjes de Sobrado decían que los campesinos eran "gente indómita, que no se pueden cobrar dellos las rentas si no es con prisiones", y refiriéndose en concreto al coto de Gomariz señalaban que sin la jurisdicción no sería fácil cobrar las rentas, "por ser en cosas muy menudas de cuartos, tercios y quintos"; los cistercienses de Oia, también con muchos foros proporcionales, se quejaban de que "les hurtan, les niegan y se levantan con sus rentas cada día", y con carácter general afirmaban que, si prosperaban las desmembraciones y ventas de jurisdicciones y cotos por parte del rey, "es cosa evidente que los monasterios se despoblarán y no se podrán sustentar aunque se les recompense en otra parte" 25 . A la vez, el granjero de San Clodio destacado en Esposende decía en

manera: el que traía Juan consigo se le dé a Pedro para que vaya mayordomar con él, y el que traía Pedro [se] le dé a Juan (...); desta suerte se ahorrará tanto gasto de jornales, advirtiéndoles que acabada la vendimia del tal forero vengan a dar cuenta de las pieças y de los cestos que han cogido"; $i b$.

${ }^{24}$ Angel Fernández González, “A fiscalidade eclesiástica...”, op. cit., pp. 292 y ss.

${ }^{25}$ María Angeles Faya, "Los señoríos eclesiásticos gallegos y la venta de jurisdicciones en tiempos de Felipe II", en José Luis Pereira y Juan Manuel Beltrán (edrs.), Felipe II y su tiempo. Actas de la V Reunión Científica. Asociación Española de Historia Moderna, Universidad de Cádiz, 1999, vol. I, pp. 101-105, y de la misma autora, "Jurisdicciones de los monasterios 
1592 que antes de autorizar la vendimia a cada colono, "conviene asimismo mirar el foral, y asentar en el memorial lo que están obligados a traer a la granja lo que deben, y executarlo un año con rigor para que teman, porque si no son vasallos del monasterio hacen lo que quieren" ${ }^{26}$. Por ello, cuando no pudieron conservar todas sus jurisdicciones y cotos, los monasterios trataron de mantener una especie de jurisdicción enfitéutica, consistente en el nombramiento de un juez para el cobro de las rentas, del que sólo se podía apelar a la Audiencia Real. En relación con esto, el autor del tumbo de A Franqueira, de mediados del XVII, advertía que si bien el conde de Salvaterra había comprado la jurisdicción de los cotos monásticos, "se le vendió dicha jurisdicción tan capada que para conservación de sus montes y de todas las demás haciendas de raíz que hay en dichos cotos se quedó el monasterio con la misma jurisdiçión civil y criminal como si no se la hubiese vendido"27.

Cabía sin duda discutir las ventajas e inconvenientes de los foros por pensión fija o proporcional, pero en lo que los cistercienses estaban de acuerdo era en administrar los prioratos por medio de monjes granjeros, en vez de arrendar la cobranza de rentas. Hacia 1680, el religioso que el monasterio de Meira tenía en el priorato de San Tirso ponderaba la utilidad de la administración directa: "siempre es bueno que esta hacienda no se arriende, pues los arrendatarios más tiran a hacer la bolsa que al augmento della [de la hacienda] y del convento, y por no gastar en pleitos dexan perder las acçiones y derechos; y se experimenta que las haciendas que se administran por los religiosos raras veces van en disminución, sino que por la mayor parte siempre están augmentadas, sabidas y declaradas, fuera de que el útil es mayor para el convento, como se ha experimentado". Para conseguir precios bajos los arrendatarios decían que a menudo se perdían los granos: "y era porque no se los quitasen y perdiesen este granillo, pues no hay duda que en el tiempo que anduvieron en arriendo perdería el convento más de seis mil ducados, y ellos los interesaron, y los

cistercienses gallegos a mediados del s. XVI", en Actas. Congreso Internacional sobre San Bernardo e o Císter en Galicia e Portugal, (Ourense), Zamora, Montecasino, 1992, p. 35.

${ }^{26}$ En Manuel Lucas Álvarez, "Una aproximación a las superficies...", op. cit., p. 473.

${ }^{27}$ Francisco Xavier Limia Gardón, "Santa María de A Franqueira”, en Fray Ma Damián Yáñez Neira, Monasticón, op. cit., I, p. 282. Los casos en que los monasterios se reservan la jurisdicción para el cobro de rentas son abundantes; otros ejemplos en Pegerto Saavedra, Das casas de morada ó monte comunal, Santiago de Compostela, Xunta de Galicia, 1996, pp. 367 y ss. 
granos ha muchos años que se conservan tan bien como en otras partes, y que no entra en ellos el gorgoxo..."28.

No parece que los foros, fuesen proporcionales o fijos, hayan condicionado de modo decisivo la evolución de los cultivos ${ }^{29}$. Éstos se transformaron más o menos de acuerdo con las condiciones edafológicas y climáticas de cada comarca, con aparente independencia de las formas de cesión de la tierra. En las zonas en las que se difundió el maíz, la estructura de las rentas forales de carácter fijo quedó más o menos distanciada de la composición de las cosechas de los campesinos, aunque las situaciones varían, y algunos monasterios aprovecharon las renovaciones de los contratos para actualizar las cargas estipuladas en cereal. Conforme avanzaba la Edad Moderna, los campesinos hicieron un uso creciente de la posibilidad que se les ofrecía de satisfacer en dinero, a los precios fijados por las justicias locales, rentas fijadas en especie $\mathrm{y}$, de acuerdo con determinadas equivalencias, también se les admitía un cereal en vez de otro que iba desapareciendo de los campos. En 1828, por tanto poco antes de la exclaustración, el monasterio de Celanova comenzó un nuevo libro de granería (panera), en cuyas primeras páginas se contienen una serie de advertencias sobre el modo de cobrar las rentas. Dos de ellas se refieren a cereales en retroceso o desaparecidos, el centeno y el mijo respectivamente: "Por cuanto la renta que tienen los foros suele ser generalmente con la pensión de pagar centeno, y que por la falta de este grano acostumbran los colonos a pagar maíz en lugar de centeno, cuya medida [del maíz] es mayor por darse colmada o acugulada; no obstante que ellos lo hacen libre y espontáneamente, y por su propia conveniencia, interés y utilidad, se les debe hacer presente que no tienen más obligación que la de pagar sus foros en especie o grano de centeno, o su valor, según las valías de los meses de mayo y junio; y asimismo, advierten los padres graneros que el recibir maíz por centeno, cuando los renteros lo hacen, aun siendo mayor el valor de aquél, constituye al monasterio en la obligación de tomárselo, aunque algún año o años valga más el centeno; porque así lo

${ }^{28}$ Archivo Histórico Nacional (Madrid), Clero, libro 6.433 de Meira, anotaciones al final del tumbillo.

${ }^{29}$ La cuestión de la posible influencia de las rentas en especie sobre los tipos de cultivos, y por tanto sobre la iniciativa campesina, fue tema muy debatido hace años; vid. Jaime García Lombardero, La agricultura y el estancamiento económico de Galicia en la España del Antiguo Régimen, Madrid, Siglo XXI, 1973, quien sostiene que las rentas forales fijaban los cultivos (pp. 41 y 95, por ejemplo). Por el contrario, otros autores, como José Manuel Pérez García, afirman que el sistema de cultivos evolucionó al margen de la composición de las rentas; cf. Un modelo de sociedad rural de la Galicia costera, Universidad de Santiago, 1979, pp. 175-176. La razón está, básicamente, de parte de este autor, aunque no cabe descartar cierta influencia de foros y diezmos en el freno, por ejemplo, a la expansión de la patata. 
pide la equidad y justicia de un contrato tácito y de sólo hecho, fundado en el principio vulgar (pero cierto), qui sentit commodum, debet sentit incommodum. Estas advertencias deben tenerse siempre muy presentes..."30.

También era preciso buscar una solución a las rentas estipuladas en mijo, una vez que este cereal dejara de cultivarse en la comarca: "Hay algunos foros y patronatos que, además de la renta de trigo, centeno o cebada, traen algunas fanegas o tegas de menudo, esto es, millo menudo. Cuando se hicieron dichos foros era común este grano, y se pagaba en la propia especie por la tega de maíz (o la de centeno acugulada). Hace ya años que se ha desterrado (por el recelo de los pájaros o gorriones) esta semilla de este partido. Desde entonces comenzó a alterarse la paga y cobranza de este freto, pues unos a falta del menudo pagaban centeno por su propia medida rasa o común, otros pagaban y pagan maíz, o como llaman vulgarmente millo groso, por su medida, esto es, acugulada; y otros, en fin, pagan el maíz o millo groso por la medida rasa del centeno, y ésta es la que parece paga más equitativa, porque el menudo ni vale tanto como el maíz medida por medida, ni vale tampoco como la media medida, o medio precio del maíz, como quieren algunos fundados en que el menudo es medio fruto o medio precio del maíz". De esta variedad se aprovechaban los cabezaleros o encargados de cobrar las rentas de un determinado foral y llevarlas a la granería del monasterio ${ }^{31}$.

Para evitar inconvenientes y los robos perpetrados por los cabezaleros del monasterio de Celanova, el medio más seguro en la cobranza era percibir las rentas en la propia especie de mijo o centeno y maíz por sus correspondientes medidas: "que los padres graneros prevengan a los cabezaleros que avisen a sus conforeros que paguen la renta del menudo en su propia especie, comprándolo

${ }^{30}$ Archivo Histórico Provincial de Ourense, Clero, libro 234 de Celanova, advertencias preliminares.

31 "En medio de esta disparidad de opiniones -continúan las advertencias de la granería de Celanova- los cabezaleros de dichos foros prescinden de toda duda, y sin escrúpulo alguno cobran y aun obligan a pagar a los colonos la renta del menudo por medida llena y entera, cual sea en centeno por la medida del trigo y centeno, y si es o pagan en maíz por la medida acugulada de este fruto; y si después les falta alguna renta para completar sus foros (que siempre procuran que les falte, por la cuenta que les tiene), erre que erre que los padres graneros les han de cobrar las faltas del foro (que siempre dicen que son de menudo, porque no se lo pagaron, a causa de no cogerse en el país) al medio precio del valor del centeno (...); en cuya pretensión insisten de unos años a esta parte para ganar nada menos que una mitad con este tráfico y tramoya; pues es constante y evidente que el menudo que no les pagan a los cabezaleros los colonos en su propia especie ni en la centeno y maíz, según queda dicho arriba, lo cobran los dichos cabezaleros a los renteros al precio que en la granería se cobra el centeno, sin rebaja ni aumento alguno, como está bien averiguado". 
en las inmediaciones (pues lo hay en la parroquia de Espinoso, de Puentedeva y otras, y a los padres graneros y al monasterio les tendrá mucha cuenta este grano para las gallinas y palomas, etc.), o que, si no quieren tomarse la molestia de buscar y comprar el menudo, en tal caso lo paguen o en centeno por su medida propia o en maíz por la de este fruto, porque de cualquier otro modo la cobranza es enredadísima, y expuesta a cobrar más o menos que lo justo"32.

Según el padre Sarmiento, los campesinos habían vuelto a cultivar mijo precisamente para evitar que los perceptores de rentas se aprovechasen de la falta de este fruto: "Todas las rentas antiguas de Galicia, sus granos, están a pan mediado, y significa 'mitad en centeno' y ‘mitad en mijo menudo'. Sucedió que, como se sembraba poco mijo, pagaban los labradores el mijo no en especie, sino en dinero. Viendo esto los cobradores de las rentas, cada año valuaban más el ferrado de mijo, por lo mismo que se sembraba poco, y crecían las extorsiones. Abrieron los ojos los labradores, y volvieron a sembrar mijo para pagar la renta en especie. Así se hace, y que el cobrador tase a doblón de ocho el ferrado de mijo, y busque quien se lo compre" 33 .

El caso es que la presencia del mijo en las rentas de algunas comunidades regulares continuaba siendo importante a fines del XVIII, cuando según fuentes diversas ese cultivo tenía carácter residual o había desaparecido de varias comarcas. Sin duda una parte de las cargas forales las percibían los religiosos en dinero, a los precios fijados en las "fes de valores", pero no todos, según pone de manifiesto la distribución real del gasto en especie de diversos monasterios en las décadas de 1770-1780:

${ }^{32} \mathrm{Ib}$. La equidad preocupa a los religiosos, de ahí las opciones que ofrecen a los colonos: “y los padres graneros podrán, asentado este principio o especie de contrato, cobrar tuta constientia la tega o tegas o fanegas del menudo faltoso al precio o valor del centeno; todo esto salvo meliori...".

${ }^{33}$ Fr. Martín Sarmiento, "Obra de 660 pliegos", XIII/1.023 (utilizo la transcripción de que dispone el Consello da Cultura Galega). 
Cuadro - Ingresos cerealeros de los monasterios de Poio, Tenorio y Lérez, y salidas del de Poio, en la etapa final del Antiguo Régimen. Media en hls/año

a) Ingresos

\begin{tabular}{lrrrrrrrrrrr}
\hline Monasterio & Años & \multicolumn{1}{c}{ Trigo } & \multicolumn{1}{c}{$\%$} & Centeno & $\%$ & \multicolumn{1}{c}{ Mijo } & \multicolumn{1}{c}{$\%$} & \multicolumn{1}{c}{ Maíz } & $\%$ & \multicolumn{1}{c}{ Total } & $\%$ \\
\hline Poio & $1781-84$ & 158,5 & 8,5 & 717,3 & 38,5 & 548,6 & 29,4 & 440 & 23,6 & $1.864,4$ & 100 \\
Poio & $1814-24$ & 253,1 & $13,-$ & 774,2 & 39,9 & 606,1 & 31,2 & 309,3 & 15,9 & $1.942,7$ & 100 \\
Tenorio & $1777-84$ & 8,9 & 1,4 & 118,2 & 18,6 & 104,5 & 16,4 & 404,9 & 63,6 & 636,5 & 100 \\
Tenorio & $1814-18$ & 9,9 & 1,6 & 124,9 & 20,4 & 98,5 & 16,1 & 378,7 & 61,9 & $612,-$ & 100 \\
Lérez & $1814-18$ & 145,7 & 14,7 & 387,9 & 39,1 & 320 & 32,2 & 138,4 & $14,-$ & 992 & 100 \\
\hline
\end{tabular}

b) Salidas o "gastos"

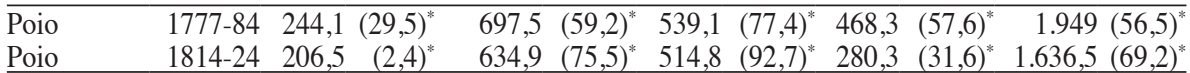

* Porcentaje que representan las ventas en las salidas totales.

Fuente: Elaboración a partir de los fondos documentales digitalizados, procedentes del Archivo de la Congregación Benedictina (Silos), incorporados al volumen Opus Monasticorum. Patrimonio, Arte, Historia y Orden, coord. José Manuel López Vázquez, Santiago de Compostela, Xunta de Galicia, 2005.

Tanto en Poio como en Lérez, los ingresos de mijo representan cerca de un tercio del total, y en vísperas de la exclaustración superan ampliamente a los del maíz. En cambio, los correspondientes al pequeño monasterio de Tenorio, situado como los anteriores en las Rías Baixas, se ajustan más al sistema de cultivos de la Galicia sudoccidental, quizá por incluir una porción significativa de diezmos ${ }^{34}$. Ahora bien, si se repara en los porcentajes que suponen las ventas sobre las salidas totales, en Poio se advierte que el mijo es el cereal más comercializado: el 77,4 por cien en 1777-84 y el 92,7 en vísperas de la exclaustración se destinan con teoría al mercado, lo que significa en realidad, como ya señalara en una obra fundamental el prof. José Manuel Pérez García, que los colonos satisfacen en dinero rentas fijadas en especie, operación que los padres paneros y los mayordomos asimilan a una venta, de acuerdo con su lógica contable ${ }^{35}$. Así, conforme el mijo retrocede, más se comercializa en apariencia, esto es, más recurren los campesinos a pagar los foros a las "fes de valores", o precios estipulados por las autoridades locales.

El estudio del diverso empleo de los cereales no comercializados ratifica lo que acabamos de señalar:

${ }^{34}$ No es seguro que los diezmos se incluyan siempre en Poio, en donde alude a su existencia en espiga. Las cifras no se refieren a las rentas totales, sino a las percibidas en la casa central (faltan las de los prioratos).

35 José Manuel Pérez García, Un modelo de sociedad rural, op. cit., pp. 284-285. 
Cuadro - Empleo de los cereales no comercializados, en tres monasterios benedictinos.

Media hls/año

\begin{tabular}{|c|c|c|c|c|c|c|c|c|c|c|}
\hline \multicolumn{11}{|c|}{ Monasterio de Poio, $1777-1784$} \\
\hline & $\begin{array}{l}\text { Consumo } \\
\text { de los } \\
\text { religiosos }\end{array}$ & $\%$ & $\begin{array}{c}\text { Consumo } \\
\text { de criados, } \\
\text { oficiales }\end{array}$ & $\%$ & Limosnas & $\%$ & Otros & $\%$ & Total & $\%$ \\
\hline Trigo & 205,7 & 100 & 31,2 & 21,6 & - & - & 2,8 & 3,5 & 239,7 & 28,2 \\
\hline Centeno & - & & $57,-$ & 39,5 & 155,8 & 37,1 & 71,4 & 90,4 & 284,2 & 33,5 \\
\hline Mijo & - & & 37,6 & $26,-$ & 79,9 & $19,-$ & 4,8 & 6,1 & 122,3 & 14,4 \\
\hline Maíz & - & & 18,7 & 12,9 & 184,1 & 43,9 & - & & 202,8 & 23,9 \\
\hline Total & 205,7 & 100 & 144,5 & 100 & 419,8 & 100 & 79 & 100 & 849 & 100 \\
\hline \multicolumn{11}{|c|}{ Id., 1814-24 } \\
\hline Trigo & 139,4 & & & & 1,3 & 0,6 & 4,8 & 5,9 & 145,5 & 27,5 \\
\hline Centeno & - & & 17,7 & 19,1 & 108,4 & $50,-$ & 29,4 & 36,1 & 155,5 & 29,3 \\
\hline Mijo & - & & 7,5 & 8,1 & 23,3 & 10,7 & 6,8 & 8,4 & 37,6 & 7,1 \\
\hline Maíz & - & & 67,3 & 72,8 & 83,9 & 38,7 & 40,4 & 49,6 & 191,6 & 36,1 \\
\hline Total & 139,4 & 100 & 92,5 & 100 & 216,9 & 100 & 81,4 & 100 & 530,2 & 100 \\
\hline \multicolumn{11}{|c|}{ Monasterio de Lérez, 1777-84 } \\
\hline Trigo & 129 & 100 & - & & - & - & 0,8 & 1,1 & 129,8 & 27,5 \\
\hline Centeno & - & & 22,5 & 31,5 & 56,3 & 28,4 & 46,5 & $64,-$ & 125,3 & 26,6 \\
\hline Mijo & - & & 40,2 & 56,3 & 71,3 & $36,-$ & 17,4 & $24,-$ & 128,9 & 27,4 \\
\hline Maíz & - & & 8,7 & 12,2 & 70,6 & 35,6 & 7,9 & 10,9 & 87,2 & 18,5 \\
\hline Total & 129 & 100 & 71,4 & 100 & 198,2 & 100 & 72,6 & 100 & 471,2 & 100 \\
\hline \multicolumn{11}{|c|}{ Id., 1814-24 } \\
\hline Trigo & 81 & 100 & & & & & 2,2 & 31,2 & 83,2 & 24,9 \\
\hline Centeno & - & & $\leftarrow$ & 66,5 & $\rightarrow$ & $36,--$ & 25,9 & 37,5 & 92,4 & 27,6 \\
\hline Mijo & - & & $\leftarrow$ & 36,8 & $\rightarrow$ & 19,9 & 9,8 & 14,2 & 46,6 & 13,9 \\
\hline Maíz & - & & $\leftarrow$ & 81,5 & $\rightarrow$ & 44,1 & 31,1 & 45,1 & 112,6 & 33,6 \\
\hline Total & 81 & 100 & $\leftarrow$ & 184,8 & $\rightarrow$ & 100 & 69 & 100 & 334,8 & 100 \\
\hline \multicolumn{11}{|c|}{ Monasterio de Tenorio, $1777-84$} \\
\hline Trigo & 21,6 & 100 & - & & - & & - & & 21,6 & 12,3 \\
\hline Centeno & - & & 4,5 & 28,8 & $35,6^{*}$ & 31,3 & 15,3 & & 55,4 & 31,6 \\
\hline Mijo & - & & 0,9 & 5,8 & $74,3^{*}$ & 65,4 & 2,5 & & 77,7 & 44,3 \\
\hline Maíz & - & & 10,2 & 65,4 & 3,7 & 3,3 & 6,9 & & 20,8 & 11,8 \\
\hline Total & 21,6 & 100 & 15,6 & 100 & 113,6 & 100 & 24,7 & & 175,5 & 100 \\
\hline \multicolumn{11}{|c|}{ Id., 1814-24** } \\
\hline Trigo & $\rightarrow$ & & $\rightarrow$ & & $\rightarrow$ & & $\rightarrow$ & & 23,3 & 9,5 \\
\hline Centeno & $\rightarrow$ & & $\rightarrow$ & & $\rightarrow$ & & $\rightarrow$ & & 65,9 & $27,-$ \\
\hline Mijo & $\rightarrow$ & & $\rightarrow$ & & $\rightarrow$ & & $\rightarrow$ & & 47,1 & 19,3 \\
\hline Maíz & $\rightarrow$ & & $\rightarrow$ & & $\rightarrow$ & & $\rightarrow$ & & $108,-$ & 44,2 \\
\hline Total & $\rightarrow$ & & $\rightarrow$ & & $\rightarrow$ & & $\rightarrow$ & & 244,3 & 100 \\
\hline
\end{tabular}

* Parte consumida también con jornaleros.

** Salvo en el caso del trigo, consumido por religiosos, en el resto de cereales no especifica la distribución entre los diversos capítulos.

Fuente: Elaboración a partir de los fondos documentales digitalizados, procedentes del Archivo de la Congregación Benedictina (Silos), incorporados al volumen Opus Monasticorum. Patrimonio, Arte, Historia y Orden, coord. José Manuel López Vázquez, Santiago de Compostela, Xunta de Galicia, 2005.

En Poio el mijo es un cereal bastante utilizado hacia 1780 en las limosnas y en la alimentación de criados, jornaleros eventuales y otros asalariados de la comunidad. En 1814-24 su papel puede calificarse de residual, cabiéndole al 
maíz el protagonismo fundamental -en ocasiones mezclado con el centeno-, en el consumo de la familia monástica, de los trabajadores contratados, de los pobres y de los irracionales. Otro tanto cabe decir de la comunidad de Lérez, en donde el viejo cereal de primavera tenía en 1777-84 mayor importancia en el consumo que el centeno y el maíz; y aun más claro es el caso de Tenorio: el mijo representa hacia 1780 cerca de la mitad de los diversos cereales no destinados a la venta, para ocupar el último lugar en el consumo en 1814-24, cuando a los monjes no les ha quedado más remedio que echar mano del maíz para alimentar a dependientes y pobres. Pues hay que advertir que cuando disponen de cantidades en especie de mijo, los monasterios tienden a destinarlas a gastos varios, y optan por vender centeno o maíz, cuyo precio es superior. No puede pensarse, por lo mismo, que el mijo tuviese a finales del Antiguo Régimen el mismo peso en la alimentación campesina que en la de los criados, asalariados y pobres que recibían asignaciones en cereal de las comunidades eclesiásticas.

En todo caso, parece claro que el mijo continúa siendo a fines del siglo XVIII un cereal con una presencia significativa en las rentas monásticas pagadas en las comarcas litorales y valles fluviales y en el gasto de criados, jornaleros y pobres, y ello probablemente debido, en alguna medida, a las cláusulas de los foros que tenían estipuladas las cargas en cantidades fijas. Una prueba a contrario la constituye el monasterio de Vilanova de Lourenzá, situado en la mariña cantábrica, y que apenas tenía rentas de mijo en la década de 1780 , lo que parece deberse a que esta comunidad transformó antes de 1760 muchos foros en arriendos, y así pudo acomodar en parte las rentas a los cultivos reales, cuya estructura se modificó sensiblemente entre la primera mitad del siglo XVII y el ecuador del XVIII:

\section{Cuadro - Distribución del gasto en cereales del monasterio de Lourenzá y evolución de los cultivos en el valle de Lourenzá}

a) Composición del gasto de cereales, Media anual en hls.

\begin{tabular}{ccccccccccccc}
\hline Años & Trigo & $\%$ & Centeno & $\%$ & Mijo & $\%$ & Maíz & $\%$ & Otros & $\%$ & Total & $\%$ \\
\hline $1777-84^{*}$ & $132,-$ & 20,8 & 330,8 & 52,2 & 15,4 & 2,4 & 147,4 & 23,2 & 8,6 & 1,4 & 634,2 & 100 \\
\hline
\end{tabular}

b) Estructura de los cultivos, en $\%$

\begin{tabular}{cccrc}
\hline Años & Trigo y centeno & Mijo & Maíz & Otros \\
\hline $1600-59$ & 49,4 & 45,1 & 0,3 & 5,2 \\
$1660-79$ & 56,8 & 33,9 & 7,6 & 1,6 \\
$1680-99$ & $52,-$ & 22,3 & 25,7 & - \\
c. 1752 & 35,3 & - & 64,7 & - \\
\hline
\end{tabular}

${ }^{*}$ Fdo $=17,52$ litros en todos los casos.

Fuente: Para el apartado a), las del cuadro anterior; para el b), Pegerto Saavedra, Economía, Política y Sociedad en Galicia. La provincia de Mondoñedo, 1480-1830, Madrid, Xunta de Galicia, 1985, p. 177. 
No puede decirse que la correspondencia entre cultivos y rentas sea completa, pero resulta llamativa la desaparición del mijo en las rentas de un monasterio cuyo patrimonio radicaba en una zona en la que hasta fines del XVII se cultivaba abundantemente este cereal. Por otro lado, sin duda los monjes preferían rentas de trigo e incluso de centeno a las de maíz, ya que los primeros cereales tenían un superior aprecio social.

Los monasterios se esforzaron por ajustar, en la medida de lo posible, las rentas a los cambios en el sistema de cultivos -si en ello no se veían perjudicados-, pero teniendo en cuenta la duración de los foros, "perpetuados" además en la práctica desde 1763 - o ya desde unos años antes por la fuerte oposición a los desahucios o "despojos"-, en las comarcas en donde el dinamismo agrario fue mayor la distancia entre rentas y cultivos se fue agrandando. Un buen ejemplo a la vez de acomodación repentina de las rentas forales a las transformaciones agrarias y después del inmovilismo de las primeras lo constituyen los ingresos de la panera del monasterio de Melón:

Cuadro - Ingresos de la panera del monasterio de Melón. Medias anuales en hls

\begin{tabular}{ccccccccccc}
\hline Años & Trigo & $\%$ & Centeno & $\%$ & Mijo & $\%$ & Maíz & $\%$ & Total & Indice \\
\hline $1677-79$ & 91,2 & 13,3 & 349,4 & $51,-$ & 244,4 & 35,7 & - & - & 685 & 100 \\
$1680-89$ & 93,9 & 11,9 & 382,9 & 48,5 & 246,4 & 31,2 & 65,9 & 8,4 & 789,1 & 115 \\
$1690-99$ & 98,3 & 10,6 & 361,3 & $39,-$ & 202,7 & 21,9 & 263,2 & 28,4 & 925,5 & 135 \\
$1700-09$ & 94,6 & 9,1 & 418,7 & 40,2 & 221,4 & 21,2 & 307 & 29,5 & $1.041,7$ & 152 \\
$1710-19$ & 111,1 & 10,5 & 411,5 & $39,-$ & 225,5 & 21,4 & 307,7 & 29,1 & $1.055,8$ & 154 \\
$1720-29$ & 139,9 & 12,6 & 415,7 & 37,6 & 237,6 & 21,5 & 313,1 & 28,3 & $1.106,3$ & 162 \\
$1730-39$ & 145,6 & 13,4 & 399,4 & 36,8 & 238,1 & 21,9 & 302,3 & 27,9 & $1.085,4$ & 158 \\
$1740-49$ & 153,8 & 13,8 & 411,8 & $37,-$ & 239,9 & 21,6 & 307,7 & 27,6 & $1.112,2$ & 163 \\
$1750-59$ & 144,1 & 13,2 & 402,6 & 36,9 & 238,8 & 21,9 & 306,2 & $28,-$ & $1.091,7$ & 159 \\
$1760-69$ & $133,-$ & 12,9 & 431,2 & 38,7 & 244 & 21,9 & 305,7 & 27,5 & $1.113,9$ & 163 \\
$1770-79$ & 131,7 & 12,3 & 399 & 37,1 & 238,6 & 22,2 & 305,7 & 28,4 & $1.075,-$ & 157 \\
$1780-89$ & 134,1 & 12,4 & 400,8 & 37,1 & 240,6 & 22,2 & 305,7 & 28,3 & $1.081,2$ & 158 \\
$1790-99$ & 155,7 & $14,-$ & $404,-$ & 36,4 & 244,6 & $22,-$ & 305,6 & 27,5 & $1.109,9$ & 162 \\
$1800-09$ & 161,5 & 14,4 & 407,5 & 36,4 & 245,2 & 21,9 & 305,5 & 27,3 & $1.119,7$ & 163 \\
$1810-19$ & 151,5 & 13,7 & 406,9 & 36,7 & 244,7 & 22,1 & 305,5 & 27,5 & $1.108,6$ & 162 \\
$1823-29$ & 155,7 & 16,9 & 316,5 & 34,5 & 167,8 & 18,3 & 278,2 & 30,3 & 918,2 & 134 \\
$1830-34$ & 172,4 & 16,4 & 365,2 & 34,9 & 204,4 & 19,5 & 305,5 & 29,2 & $1.047,5$ & 153 \\
\hline
\end{tabular}

Fuente: Elaboración a partir del Archivo Histórico Provincial de Ourense, Clero, libro 387.

Hasta 1687, la composición de las entradas era el resultado del predominio del centeno y del mijo entre los cultivos cerealeros: aquel proporcionaba al año de 177 a 182 fanegas de quintos y diezmos, y éste de 154 a $157^{36}$.

${ }^{36}$ Son cantidades que se repiten, porque están concertadas con los campesinos por varios años. Las rentas forales de centeno subieron de 124 a 134 fanegas entre 1677 y 1686, y las de mijo de 57 a 61 fanegas. Archivo Histórico Provincial de Ourense, Clero, libro 387. 
En las cuentas de abril de 1688, el padre panero advierte: "quitáronse este año los conciertos antiguos, y se cobró conforme a las condiciones de los foros en las eras (...), y el cobrarlos como este año le importa mucho a la casa (...), y el año que menos coge [recauda] más de lo que pagaban, añadiendo el maíz [de] que no pagaban nada". En efecto, los diezmos y quintos de la cosecha de 1687 ascendieron a 191 fanegas de centeno, 81 de mijo y 154 de maíz ${ }^{37}$, lo que supuso un incremento de las entradas de la panera del 18 por cien con respecto al quinquenio anterior. En el cuatrienio de 1688 a 1691 los diezmos de las feligresías de Melón y Quines alcanzaron las 124,25 fanegas de centeno, 102,25 de mijo y 200,1 de maíz (este cereal supone el 50 por cien de la producción, por tanto). A partir de entonces la comunidad monástica comenzó a realizar conciertos con los colonos, arrendando los diezmos por cantidades fijas o incluyéndolos en los foros, hasta que en 1698-99 los ingresos quedaron prácticamente estabilizados en unos niveles que ya oscilarían poco, al irse incorporando a los foros las cantidades que se venían percibiendo en concepto de arriendo de diezmos. Lo que provoca que las cantidades de centeno y mijo oscilen algo de año a año son las derivadas de la primicia, que los campesinos pagan en estos dos cereales (y en el caso del centeno se añaden además, a principios del XIX, de 0,5 a 3 fanegas de diezmos de las rozas) ${ }^{38}$, en tanto el maíz procede en sustancia de rentas fijas (269,25 fanegas). Sólo las rentas de trigo ascienden notablemente a partir de la década de 1720, al poner en funcionamiento el cenobio una aceña que era una verdadera "joya", arrendada según los años, de acuerdo con el estado del ingenio y las estaciones de aguas, por cantidades que iban de 20 a 60 fanegas de ese cereal.

El monasterio de Melón realizó por tanto, en el curso de una docena de años, el ajuste de las rentas de su granería a las transformaciones agrarias, ocurridas previamente, dando entrada al maíz, que hasta la enclaustración representó una cuarta parte larga de los ingresos globales administrados por el padre panero. En el sistema de cultivos el cereal americano tenía una mayor importancia, según quedó advertido al comentar la estructura de la masa decimal, pero el hecho de que después de los ajustes posteriores a 1687 la comunidad conservase las rentas y la primicia en mijo es síntoma de que este producto continuó siendo en alguna medida sembrado, consumido y vendido. Desde 1677-79 a 1700-09 las entradas

${ }^{37}$ Archivo Histórico Provincial de Ourense, Clero, libro 387, cuentas de abril de 1687. Al dar razón del recibo de maíz, el monje añade: "No se cogía [por la panera] de este fruto hasta ahora, que se quitaron los conciertos antiguos medio fallidos que había, y le importa mucho el cogérense al convento". Ibid.

${ }^{38}$ Lo cual es significativo no por las cantidades en sí, sino porque revela los intentos tardíos de los campesinos de ampliar la producción por esta vía, sin ningún éxito. 
globales de la panera aumentaron un 47,5 por cien, gracias en sustancia al maíz (sólo este cereal supuso un 40 por cien del incremento), y luego quedaron cuasi fijadas; la pequeña caída posterior al trienio deriva del arriendo de la primicia, de nuevo cobrada directamente en 1833-34. La estabilización refleja sin duda la rigidez de la renta foral, pero quizá también el bloqueo del sistema agrario, tal como sugiere el hecho de que los campesinos intentasen acudir al cultivo de rozas a partir de 1803, fecha en que por primera vez se mencionan.

Desde comienzos del XVIII las rentas de la panera de Melón se mantienen estabilizadas, pero los cambios que se advierten en el destino de los diversos cereales derivan de su mayor o menor presencia en el sistema de cultivos y en la alimentación:

Cuadro - Destino de los cereales de la panera del monasterio de Melón.

Media anual en hls

\begin{tabular}{ccccc|cccc}
\hline \multirow{2}{*}{ Años } & \multicolumn{4}{c|}{ Trigo } & \multicolumn{4}{c}{ Centeno } \\
\cline { 2 - 9 } & $\begin{array}{c}\text { Gasto en } \\
\text { especie }\end{array}$ & $\%$ & Vendido & $\%$ & $\begin{array}{c}\text { Gasto en } \\
\text { especie }\end{array}$ & $\%$ & Vendido & $\%$ \\
\hline $1677-86$ & 96,1 & 100 & - & - & $256,-$ & 69,3 & 113,6 & 30,7 \\
$1687-94$ & 115,2 & 96,6 & 4,1 & 3,4 & 273,7 & 73,3 & 99,6 & 26,7 \\
$1695-99$ & 107,2 & 98,6 & 1,5 & 1,4 & 241,7 & 62,2 & 146,7 & 37,8 \\
$1700-19$ & 106,4 & 98,4 & 1,7 & 1,6 & 233,6 & 56,6 & 179,2 & 43,4 \\
$1720-49$ & 151,5 & 99,9 & 0,8 & 0,5 & 301,3 & 74,4 & 103,7 & 25,6 \\
$1750-79$ & 170,1 & 100 & - & - & $299,-$ & 72,2 & 114,9 & 27,8 \\
$1780-99$ & 162,6 & 99,7 & 0,5 & 0,3 & 249,6 & 61,6 & 155,3 & 38,4 \\
$1800-19$ & 148,8 & 96,6 & 5,2 & 3,4 & 161,3 & 39,8 & 243,9 & 60,2 \\
$1824-34$ & 161,8 & 92,2 & 13,6 & 7,8 & 203,8 & 57,8 & 155,2 & 92,2 \\
\hline
\end{tabular}

\begin{tabular}{ccccc|cccc}
\hline \multirow{2}{*}{ Años } & \multicolumn{5}{c|}{ Mijo } & \multicolumn{4}{c}{ Maíz } \\
\cline { 2 - 9 } & $\begin{array}{c}\text { Gasto en } \\
\text { especie }\end{array}$ & $\%$ & Vendido & $\%$ & $\begin{array}{c}\text { Gasto en } \\
\text { especie }\end{array}$ & $\%$ & Vendido & $\%$ \\
\hline $1677-86$ & 214,9 & 86,2 & 34,4 & 13,8 & - & - & - & - \\
$1687-94$ & 192,8 & 94,1 & 12,1 & 5,9 & 84,1 & 37,1 & 142,6 & 62,9 \\
$1695-99$ & 145,6 & 68,6 & 66,5 & 31,4 & 93,1 & 32,1 & 197,2 & 67,9 \\
$1700-19$ & 185,6 & 82,1 & 40,6 & 17,9 & 14,5 & 4,7 & 293,8 & 95,3 \\
$1720-49$ & 207,2 & 87,5 & 29,6 & 12,5 & 17,3 & 5,8 & $283,-$ & 94,2 \\
$1750-79$ & 199,5 & 81,8 & 49,3 & 18,2 & 33,5 & 10,8 & 277,1 & 89,2 \\
$1780-99$ & 194,2 & 81,3 & 44,8 & 18,7 & $49,-$ & 16,8 & 255,7 & 83,2 \\
$1800-19$ & 113,6 & 50,7 & 110,3 & 49,3 & 109,3 & 35,7 & 196,5 & 64,3 \\
$1824-34$ & 92,1 & 47,1 & 103,4 & 52,9 & 115,1 & 36,1 & 203,8 & 63,9 \\
\hline
\end{tabular}

Fuente: Elaboración a partir del Archivo Histórico Provincial de Ourense, Clero, libro 387.

Hasta fines del XVIII, los ingresos del mijo se destinan a limosnas, consumo de criados, salarios, etc..., mientras el maíz se comercializa en su casi totalidad. A comienzos del XIX la tendencia se invierte, porque sin duda el mijo se cultiva menos y los colonos pagan en dinero una parte de las rentas estipuladas en este 
cereal; aun así, se ve que no ha desaparecido del sistema agrario del entorno del monasterio, pues sigue habiendo un significativo gasto en especie. No hay duda de que en ocasiones -y como apuntaban las instrucciones de la panera de Celanova citadas antes-, los campesinos optaban por comprar mijo en las comarcas en las que se sembraba, para satisfacer en la propia especie las rentas. Así, la granja de Outeiro, del mismo monasterio de Melón, tenía a mediados del XVIII unas rentas forales de 95 ferrados de mijo, 116 de centeno y 90 de maíz, pero el primer cereal ya no se cultivaba entonces, pues no aparece en los ingresos decimales; sin embargo, aun en 1830-34 figura un gasto en especie de 58 ferrados por año. En cambio, en la granja de Rubillón, también de Melón, las primicias continúan satisfaciéndose en teoría en mijo a principios del XIX, cuando las cosechas de maíz eran doscientas veces superiores; pero apenas hay gastos en especie del primer cereal, indicio de que los feligreses pagan en dinero las $\operatorname{cargas}^{39}$.

\section{Ingresos monásticos y sistema agrario en la Galicia interior}

Los monasterios tenían sus dominios dispersos, y en consecuencia la composición de los ingresos podía variar notablemente de unas a otras administraciones. Las comunidades con patrimonios situados preferentemente en el interior percibían sobre todo rentas de centeno, pero también algunas de mijo o maíz en los valles abrigados, además de cantidades de vino en los prioratos próximos al Sil, al Miño y a sus afluentes. El monasterio de Oseira, por ejemplo, tenía 23 prioratos y granjas, de las cuales sólo la de Marín radicaba en el litoral; el resto se distribuía por las provincias de Ourense y Lugo, a excepción de la abadía de Júnias de Pitões, en Tras-Os-Montes ${ }^{40}$. Los ingresos globales de este inmenso dominio ascendían a mediados del XVIII a unos $6.725 \mathrm{hls}$ de cereal, y a 2.500 de vino. Entre los primeros, el centeno representaba

${ }^{39}$ Vid. Isolina Rionegro Fariña, Estructura económica del Císter orensano en la fase final del Antiguo Régimen, Ourense, Caixa Ourense, 1998, pp. 181-183 y 190-195.

${ }^{40}$ Cf. Pegerto Saavedra, "Economías cistercienses del Antiguo Régimen”, op. cit. La titularidad de la abadía de Junias de Pitões obligó al monasterio de Oseira a sostener diversos pleitos en varios tribunales portugueses, que pueden seguirse en abadologios -como el mencionado en la nota 13-, o en la obra del padre Fray Tomás de Peralta, Fundación, antigüedad y progressos del imperial monasterio de Nuestra Señora de Ossea, orden del Císter, Madrid, Melchor Álvarez, 1677 (hay edición facsímil de 1997, de la Xunta de Galicia, de calidad escasa), y Continuación, desde el momento en que la dejó Peralta, del padre Fray Damián Yáñez Neira (editada también por la Xunta de Galicia, en 1997). 
el 89 o 94 por cien del total, el trigo entre el 2 y el 3 y el mijo y maíz entre el 3 y el 5,5 por cien.

Cuadro - Composición y trayectoria de los ingresos de cereales de Oseira.

Media anual en hls

\begin{tabular}{ccccccccc}
\hline Años & Trigo & $\%$ & Centeno & $\%$ & Mijo y maíz & $\%$ & Total & Índice \\
\hline $1617-19$ & 109,6 & $2,-$ & $5.055,9$ & 93,4 & 248,9 & 4,6 & $5.414,4$ & 100 \\
$1650-55$ & 177,9 & $3,-$ & $5.617,9$ & 93,4 & 218,8 & 3,6 & $6.014,6$ & 111 \\
$1672-73$ & 166,5 & 2,7 & $5.689,4$ & 93,7 & 213,3 & 3,5 & $6.069,2$ & 112 \\
$1738-40$ & 168,5 & 2,7 & $5.779,9$ & 91,4 & 374,7 & 5,9 & $6.323,1$ & 117 \\
$1791-1802$ & 203,8 & $3,-$ & $5.991,5$ & 89,5 & 499,4 & 7,5 & $6.695,-$ & 124 \\
$1828-31$ & 185,8 & 2,9 & $5.635,9$ & 88,7 & 530,6 & 8,4 & $6.352,3$ & 117 \\
\hline
\end{tabular}

Fuente: Biblioteca del monasterio de Poio (Pontevedra), Libro de estado del monasterio de Oseira.

Las entradas de trigo eran menguadas, de ahí que el padre panero de la abadía hubiera de comprar todos los años de 250 a 340 fanegas, que se añadían a las recibidas de prioratos y granjas, para hacer frente al gasto de la comunidad.

Cuadro - Trigo procedente de rentas y diezmos y de compras, que entró en las paneras de Oseira. Media anual en hls

\begin{tabular}{cccccc}
\hline Años & De rentas y diezmo & $\%$ & De compras & $\%$ & Total \\
\hline $1617-28$ & 172,2 & 43,8 & 221 & 56,2 & 393,2 \\
$1641-64$ & 179 & 42,7 & 229,3 & 57,3 & 400,3 \\
$1738-40$ & 166,5 & 35,7 & 299,5 & 64,3 & 466 \\
$1771-98$ & 209,3 & 42,2 & 253,4 & 57,8 & 462,7 \\
$1799-1818$ & 195,9 & 98,1 & 211,2 & 51,9 & 407,1 \\
$1824-31$ & 216,3 & 67,6 & 103,7 & 32,4 & 320 \\
\hline
\end{tabular}

Fuente: Biblioteca del monasterio de Poio (Pontevedra), Libro de estado del monasterio de Oseira.

El incremento del número de monjes hasta mediados del siglo XVIII implicó también un aumento del consumo de trigo, al que se hizo frente reforzando las compras y, en alguna medida, alzando las rentas forales. Éstas ascendían a 110 fanegas (96,4 hls) en 1641-43, y a 168 en vísperas de la exclaustración -un 53 por cien más-, pero el descenso de los diezmos y de la cosecha de la huerta contrarrestó casi por completo la subida de los foros. Sólo la reducción del número de monjes en la etapa final del Antiguo Régimen permitió al padre panero aminorar las compras de trigo ${ }^{41}$.

Los ingresos de centeno, que procedían en un 85 por cien de cesiones forales, oscilaron poco en el curso de dos siglos largos. Tan sólo en algunas décadas del XVIII superan en un 22-24 por cien los niveles de partida, si bien

${ }^{41}$ Las compras de trigo eran frecuentes - por obligados- en los monasterios y prioratos del interior, cuyos ingresos se componían básicamente de centeno. 
resulta significativo que en vísperas de la exclaustración definitiva, después de la breve del Trienio liberal, el monasterio perciba íntegras sus rentas, lo que evidencia que la contestación social era, por comparación a la documentada en otras áreas peninsulares, muy limitada. En cambio muestran más dinamismo las entradas de mijo y maíz, en particular las del último cereal: la razón es que corresponden en su mayor parte a prioratos vitícolas, situados en valles fluviales del interior, en los que predominaban las rentas proporcionales. A lo largo de las cuencas del Miño, Sil, Arenteiro, Arnoia, Támega o Limia se difundió el cultivo del maíz o bien desde la década de 1680 o bien ya entrado el XVIII, y continuó avanzando, a costa del mijo y de los cereales de invierno. Así sucede, por ejemplo, en el priorato de Santa Cruz do Arrabaldo, situado en las proximidades de la ciudad de Ourense, en donde la producción de maíz se multiplica por 7 entre 1750 y 1830, mientras casi desaparece la de trigo y se reduce en un tercio la de centeno ${ }^{42}$.

Pero hay que señalar que en Santa Cruz do Arrabaldo -y en otros prioratos de condiciones geográficas parecidas- la vid era el cultivo principal con diferencia, de ahí que en 1824-34, pese al espectacular aumento de los diezmos de maíz, los de vino supongan un 90 del volumen total que por ese concepto cobra el monje granjero. Por lo mismo, en las comarcas de cuasi monocultivo vitícola la expansión del maíz parece más interesante por lo que revela a propósito de las estrategias campesinas a la hora de diversificar sus recursos agrarios que por su incidencia real en la cuantía de las rentas globales de Oseira. En determinados prioratos, como O Viso, el peso del vino es tal que el maíz ni se menciona entre los diezmos desde 1750 a $1834^{43}$.

La expansión del maíz en el priorato de Santa Cruz do Arrabaldo arranca, fundamentalmente, en la década de 1770. No se trata de un caso único, pues algo parecido sucede en el de Longos, también de Oseira, y en el de Moldes, sufragáneo de Sobrado.

${ }^{42}$ Cf. Isolina Rionegro Fariña, La estructura económica del Císter orensano..., op. cit., pp. 288-290. El vino continúa monopolizando casi la producción agraria a comienzos del XIX, pese a que la producción cae desde 1750 un 23 por cien y la de maíz, como quedó indicado, se multiplica por 7 .

${ }^{43}$ Isolina Rionegro Fariña, La estructura económica del Císter orensano..., op. cit., pp. 276-279. 
Cuadro - Trayectoria de los diezmos de cereales en Moldes y Longos.

Medias anuales en hls

\begin{tabular}{ccccccc}
\hline \multicolumn{7}{c}{ a) Moldes } \\
\hline Años & Trigo y centeno & $\%$ & Mijo & $\%$ & Maíz & $\%$ \\
\hline $1640-49$ & 28,2 & 100 & - & - & - & - \\
$1650-59$ & 25,3 & 100 & - & - & - & - \\
$1660-69$ & 27,6 & 100 & - & - & - & - \\
$1670-79$ & 32,5 & 100 & - & - & - & - \\
$1680-89$ & 20,5 & 100 & - & - & - & - \\
$1690-99$ & 18,3 & 100 & - & - & - & - \\
$1700-09$ & 19,6 & 100 & - & - & - & - \\
$1710-19$ & 30,8 & 60,5 & 14,8 & 29,1 & 5,3 & 10,4 \\
$1720-29$ & 25,6 & 60,2 & 9,1 & 21,4 & 7,8 & 18,4 \\
$1730-39$ & 19,3 & 50,1 & 8,8 & 22,9 & 10,4 & $27,-$ \\
$1740-49$ & 22,7 & 52,8 & 10,5 & 24,4 & 9,8 & 22,8 \\
$1750-59$ & $19,-$ & 52,2 & 8,5 & 23,4 & 8,9 & 24,4 \\
$1760-69$ & 18,4 & 47,3 & $12,-$ & 30,8 & 8,5 & 21,9 \\
$1770-79$ & 17,5 & $42,-$ & 10,1 & 24,2 & 14,1 & 33,8 \\
$1780-89$ & 18,3 & 38,4 & 7,6 & 15,9 & 21,8 & 45,7 \\
$1790-99$ & $18,-$ & 39,8 & 7,7 & $17,-$ & 19,5 & 43,2 \\
$1800-09$ & 16,5 & 37,8 & 6,1 & $14,-$ & $21,-$ & 48,2 \\
$1810-19$ & 16,1 & 36,9 & 3,7 & 8,5 & 23,8 & 54,6 \\
$1825-34$ & 19,6 & 40,5 & 2,7 & 5,6 & 26,1 & 53,9 \\
\hline
\end{tabular}

b) Longos

\begin{tabular}{ccccccc}
\hline Años & Trigo y centeno & $\%$ & Mijo & $\%$ & Maíz & $\%$ \\
\hline $1640-49$ & - & - & - & - & - & - \\
$1650-59$ & - & - & - & - & - & - \\
$1660-69$ & - & - & - & - & - & - \\
$1670-79$ & - & - & - & - & - & - \\
$1680-89$ & - & - & - & - & - & - \\
$1690-99$ & - & - & - & - & - & - \\
$1700-09$ & - & - & - & - & - & - \\
$1710-19$ & - & - & - & - & - & - \\
$1720-29$ & - & $56,-$ & 33,4 & 32,6 & 11,7 & 11,4 \\
$1730-39$ & 57,4 & 54,5 & $34,-$ & 32,2 & $14,-$ & 13,3 \\
$1740-49$ & 57,4 & 55,3 & 26,7 & 28,3 & 15,5 & 16,4 \\
$1750-59$ & 52,3 & 46,8 & 30,2 & 26,9 & 29,5 & 26,3 \\
$1760-69$ & 52,6 & $43,-$ & 20,4 & $19,-$ & 40,7 & $38,-$ \\
$1770-79$ & $46,-$ & 40,1 & 14,5 & 12,6 & 54,5 & 47,3 \\
$1780-89$ & 46,3 & 33,5 & 9,6 & 8,4 & 66,4 & 58,1 \\
$1790-99$ & 38,2 & 21,9 & $4,-$ & 4,4 & 66,6 & 73,7 \\
$1800-09$ & 19,8 & 25,8 & 1,1 & 1,2 & $69,-$ & $73,-$ \\
$1810-19$ & 24,4 & 27,5 & 0,9 & 1,2 & 55,2 & 71,3 \\
$1825-34$ & 21,3 & & & - & - \\
\hline
\end{tabular}

Fuente: Arquivo do Reino de Galicia, Monasterios, Libros 122, 195 y 196 de Sobrado (Moldes) y Arquivo Histórico Provincial de Ourense, Clero, libro 613 antiguo (Longos).

En el priorato de Moldes, hasta la segunda década del siglo XVIII no figuran los cereales de primavera entre los diezmos o porque no se cultivan o porque su presencia en las labranzas es insignificante. Lo más llamativo no resulta por 
tanto la tardía expansión del maíz, sino la del mijo, que alcanza gran importancia hasta la década de 1760. Son las crisis de ese período las que dan el impulso definitivo al maíz, en perjuicio del mijo y en alguna medida del centeno. La planta americana es la responsable de que en este priorato vitícola los cereales alcancen un peso creciente en la economía campesina: representaban el 20 por cien del volumen de la producción en 1640-49; el 25 en 1750-59, y el 55 en 1824-34, en parte también por el fuerte descenso de la producción de vino en la etapa final del Antiguo Régimen ${ }^{44}$. En Longos, por otro lado, aunque no se cultiva vino, la tendencia de los distintos cereales desde mediados del XVIII es parecida a la de Moldes: el mijo mantiene un papel decoroso hasta 1760-69 , lo que acredita una vez más su importancia como planta transformadora del sistema agrario, y el maíz sólo le supera en la década de 1770, para notar a partir de entonces una fuerte expansión, que le lleva a convertirse a principios del XIX en el cereal básico para la economía campesina, multiplicando casi por 7 sus cosechas entre 1730-39 y 1790-99.

Como quedó indicado, los ingresos de Oseira, formados básicamente por centeno, tendieron a la estabilidad desde comienzos del XVII a la desamortización, en buena medida por proceder de rentas forales de carácter fijo. Pero incluso en aquellos cenobios o administraciones que percibían cantidades significativas de diezmos en comarcas en donde apenas se cultivaba otro cereal que el mencionado, los cambios en la tipología y volumen de ingresos fueron escasos, porque tampoco los hubo en el sistema agrario, salvo ya tardíamente con la expansión de la patata, que rara vez repercutió en las rentas monásticas, aunque sí, y mucho, en las economías campesinas ${ }^{45}$. Los ejemplos de la panera de Montederramo y de su priorato Castro de Rei de Lemos así lo demuestran:

${ }^{44}$ Pegerto Saavedra, Das casas de morada, op. cit.,pp. 227-230. Al final del presente trabajo pueden verse las series de la producción de vino blanco y tinto en Moldes y otros prioratos sitos en el Ribeiro de Avia.

${ }^{45}$ Cuando los monasterios cobraron diezmos de patatas no solían percibirlo en especie: el de Monfero, por ejemplo, los cobraba desde la década de 1760 en dinero; el de Xunqueira de Espadañedo acordó con los campesinos que le pagasen en centeno en proporción a la superficie sembrada de patatas: el de Meira, en el priorato de Santa María de Moreira los cobraba, en cambio, en especie; Arquivo do Reino de Galicia, Mosteiros, libro 282 de Monfero (Panera); Arquivo Histórico Provincial de Ourense, Clero, libro 796 de Xunqueira de Espadañedo (Panera), y Archivo Histórico Nacional de Madrid, Clero, libro 6.229 de Meira (cuentas del priorato de Moreira, en los años previos a la exclaustración; los diezmos de patatas se miden en fanegas, algo habitual en la época). 
Cuadro - Trayectoria de las rentas del priorato de Castro de Rei de Lemos y de la panera del monasterio de Montederramo. Medias anuales en hls

\begin{tabular}{|c|c|c|c|c|c|c|c|c|c|c|}
\hline \multirow[b]{3}{*}{ Años } & \multicolumn{6}{|c|}{ Castro de Rei } & \multicolumn{4}{|c|}{ Montederramo } \\
\hline & & & De & & & & Ingresos & & & \\
\hline & $\begin{array}{c}\text { Ingresos } \\
\text { totales }\end{array}$ & Índice & $\begin{array}{l}\text { diezmos } \\
\text { de } \\
\text { centeno }\end{array}$ & $\begin{array}{l}\text { Índice } \\
\text { diezmos }\end{array}$ & $\begin{array}{c}\text { Diezmos } \\
\text { de trigo }\end{array}$ & Índice & $\begin{array}{l}\text { totales de } \\
\text { la panera } \\
\text { en centeno }\end{array}$ & Índice & $\begin{array}{c}\text { diezmos } \\
\text { de } \\
\text { centeno }\end{array}$ & $\begin{array}{l}\text { Índice } \\
\text { diezmos }\end{array}$ \\
\hline $1640-49$ & 467,8 & 89 & 176,3 & 91 & 17,2 & 410 & - & - & - & - \\
\hline $1650-59$ & 481 & 91 & 174,3 & 90 & 14,8 & 352 & - & - & - & - \\
\hline $1660-69$ & 504,6 & 96 & 185,6 & 96 & 14,1 & 336 & - & - & - & - \\
\hline $1670-79$ & 512,3 & 97 & 185,9 & 96 & 8,9 & 212 & - & - & - & - \\
\hline $1680-89$ & 524,7 & 100 & 172,4 & 89 & 9,6 & 229 & - & - & - & - \\
\hline $1690-99$ & $538,-$ & 102 & 171,3 & 89 & $10,-$ & 238 & - & - & - & - \\
\hline 1700-09 & $588,-$ & 112 & 225,7 & 117 & 9,2 & 219 & - & - & - & - \\
\hline $1710-19$ & 544,2 & 103 & 209,7 & 109 & 10,4 & 248 & $1.259,2$ & 98 & 136,3 & 85 \\
\hline $1720-29$ & 524,6 & 100 & $188,-$ & 97 & 3,7 & 88 & $1.280,4$ & 99 & 168,5 & 105 \\
\hline $1730-39$ & 491,5 & 93 & 161 & 83 & 3,1 & 74 & $1.285,7$ & 100 & 158,5 & 99 \\
\hline $1740-49$ & 520,6 & 99 & 190,9 & 99 & 4,4 & 105 & $1.268,4$ & 98 & 145,8 & 91 \\
\hline $1750-59$ & 527,1 & 100 & 193,- & 100 & 4,2 & 100 & $1.290,8$ & 100 & 160,2 & 100 \\
\hline $1760-69$ & 487,6 & 93 & 153,7 & 80 & 2,9 & 69 & $1.249,3$ & 98 & 120,4 & 75 \\
\hline $1770-79$ & 509,1 & 97 & 174,8 & 91 & 1,6 & 38 & 1.275 & 99 & 155,4 & 97 \\
\hline $1780-89$ & 534,1 & 101 & 137,3 & 71 & 1,4 & 33 & $1.327,5$ & 103 & 205,2 & 128 \\
\hline $1790-99$ & 510,7 & 97 & 179,7 & 93 & 1,2 & 29 & $1.339,1$ & 104 & 213,4 & 133 \\
\hline 1800-09 & 504,1 & 97 & 168,6 & 87 & 0,6 & 14 & $1.313,9$ & 102 & 203,2 & 127 \\
\hline $1810-19$ & 464,5 & 88 & 131,8 & 68 & 0,5 & 12 & $1.240,4$ & 96 & 143,4 & 90 \\
\hline $1825-34$ & 535 & 101 & 200,3 & 104 & 0,3 & 7 & $1.232,8$ & 96 & 139,1 & 87 \\
\hline
\end{tabular}

Fuente: Arquivo Histórico Provincial de Ourense, Clero, libros 473, 650 y 458 de Montederramo.

La serie de Castro de Rei es la más antigua y a juzgar por los diezmos mayores diríase que nos hallamos en presencia de un sistema agrario inmóvil. Tampoco la producción nota, en la larga duración, grandes fluctuaciones. Con la base 100 en $1750-59$ se ve que en las décadas posteriores a 1640 son frecuentes los índices por encima de 90. Los mejores años del XVIII son los que van de 1710 a 1719, cuando se supera el índice 115, cosa que ya no volverá a suceder en ningún decenio de la centuria deciochesca, aunque en 1825-34 la producción de centeno alcanza de nuevo cotas altas ${ }^{46}$. Entre otras cosas, esta evolución de la serie debe significar que el fraude decimal en los frutos mayores es inexistente en el primer tercio del XIX o, si existe, no presentará

${ }^{46}$ A partir de numerosas curvas de producción, elaboradas con las series de arriendos de cabildos catedralicios y mitras, el prof. Antonio Eiras Roel demostró hace años que el producto agrario aumentaba mucho menos en la Galicia interior que en el litoral y prelitoral; vid., de este autor, Estudios sobre agricultura y población en la España Moderna, Santiago de Compostela, Tórculo Edicións, 1991 (vol. 3 de la colecc. Sémata), pp. 85-110 (Comunicación presentada en 1977 al Coloquio de París sobre el diezmo) 
novedad con respecto al practicado regularmente por los campesinos ${ }^{47}$. La recuperación y ascenso de la producción -recuperación desde 1812, ascenso decidido a partir de 1825- han de relacionarse con un proceso de roturaciones urgidas por el crecimiento demográfico del que tenemos numerosas evidencias en medio centenar de series de bautizados de toda la provincia de Lugo o en indicios más imprecisos y aislados, como la remodelación de la propia iglesia parroquial de Castro de Rei en la década de 1790, por haberse quedado pequeña para el gran concurso de gentes que asistía a los divinos oficios.

Pero lo que en nuestra opinión es el rasgo más destacado de la serie de diezmos de centeno de Castro de Rei, observada durante dos siglos, es que fluctúa mucho menos que las del litoral y también que las de Castilla. En Castilla y León, con unas rotaciones de cultivos parecidas a las que regían en Lugo -aunque había también profundas diferencias en la estructura de la cabaña ganadera, tamaño de las explotaciones, formas de trabajo...-, la producción asciende desde una cubeta situada a mediados del XVII, o algo más tarde, según los casos, y la recuperación significa que se duplican con largueza los niveles de partida $^{48}$. No es este el caso de Castro de Rei, en donde no es posible delimitar grandes fases expansivas o depresivas y los ciclos de buenas o malas cosechas pueden explicar, casi por completo, el ascenso o descenso de los índices.

A juzgar por el nivel de la producción ni siquiera a fines del XVIII y comienzos del XIX está justificado hablar, ni en Castro de Rei ni en Montederramo, de una crisis agraria; a lo sumo se registran unos años de malas cosechas $(1800,1802,1809-11,1817$ y 1819 , en este año por el pedrisco) que alternan con otros de bonanza $(1803-6,1815-16)$. Pero la aparición de años malos con una frecuencia superior a lo normal no ha de identificarse con una verdadera crisis, que implicaría el hundimiento de la producción, el abandono de tierras, el descenso del número de vecinos... Al margen de ello, los ingresos totales oscilan menos que los diezmos, por su importante componente de rentas

${ }^{47}$ Hace tiempo que Esteban Canales puso de manifiesto que Galicia era uno de los territorios españoles en donde en la etapa final del Antiguo Régimen el fraude decimal parece más reducido. Vid., de este autor, "Los diezmos en su etapa final", en Gonzalo Ares, edr., La economía española al final del Antiguo Régimen. I. Agricultura, Madrid, Alianza Editorial, 1982, pp. 103-187.

${ }^{48}$ Vid. los numerosos datos que acopia Alberto Marcos Marín en "El crecimiento agrario castellano del siglo XVIII en el movimiento de larga duración. ¿Mito o realidad?”, in Estructuras agrarias y reformismo ilustrado en la España del siglo XVIII, Madrid, Ministerio de Agricultura, Pesca y Alimentación, 1989. 
forales de carácter fijo, que llegan prácticamente íntegras a la exclaustración, como también sucedía en Oseira. ${ }^{49}$

Con todo, en algunas comarcas del interior los campesinos ensayaron diversas vías para tratar de incrementar, y en ocasiones diversificar, la producción. A este respecto, los libros de cuentas de la granja de Solme, denominada también priorato de Carballar, dependiente de Sobrado y con el dominio radicado entre Guitiriz y Aranga, resultan de interés para ilustrar las permanencias y los pequeños cambios en una economía casi de montaña, y de su repercusión en los ingresos monásticos.

Cuadro - Rentas proporcionales a la cosecha en el priorato de Solme, sufragáneo de Sobrado. Media anual en hls

\begin{tabular}{crrrrrrrrrrr}
\hline Años & Centeno & ${ }^{*}$ & \multicolumn{1}{c}{$\%$} & $(\%)^{* *}$ & \multicolumn{1}{r}{ Mijo } & \multicolumn{1}{r}{$\%$} & $(\%)^{* * *}$ & Avenas & \multicolumn{1}{r}{ Total } & Índice \\
\hline $1636-39$ & 141,7 & $(?)$ & 77,1 & $(?)$ & $20,-$ & 10,9 & $(12,4)$ & 22,1 & $12,-$ & 183,8 & 100 \\
$1640-49$ & $121,-$ & $(?)$ & 77,4 & $(?)$ & 12,7 & 8,1 & $(9,5)$ & 22,7 & 14,5 & 156,4 & 85 \\
$1650-59$ & 155,2 & $(?)$ & 84,7 & $(?)$ & 14,7 & $8,-$ & $(8,7)$ & 13,3 & 7,3 & 183,2 & 100 \\
$1690-99$ & 95,8 & $(3,3)$ & 85,6 & $(3,4)$ & 8,5 & 7,6 & $(8,4)$ & 7,6 & 6,8 & 111,9 & 61 \\
$1700-09$ & 104,7 & $(?)$ & 78,8 & $(?)$ & 19,5 & 14,7 & $(15,7)$ & 8,6 & 6,5 & 132,8 & 72 \\
$1710-19$ & 90,6 & $(2,4)$ & 74,5 & $(2,6)$ & 18,6 & 15,3 & $(17,5)$ & 12,4 & 10,2 & 121,6 & 66 \\
$1720-29$ & 96,4 & $(12,4)$ & 71,8 & $(12,9)$ & 25,8 & 19,2 & $(23,5)$ & 12,1 & $9,-$ & 134,3 & 73 \\
$1730-39$ & 99,1 & $(21,8)$ & 72,8 & $(22,-)$ & 25,4 & 18,6 & $(24,7)$ & 11,7 & 8,6 & 136,2 & 74 \\
$1740-49$ & 162,4 & $(18,9)$ & 79,3 & $(11,6)$ & 24,7 & $12,-$ & $(14,7)$ & 17,8 & 8,7 & 204,9 & 111 \\
$1750-59$ & 138,8 & $(25,8)$ & 82,5 & $(18,6)$ & 18,9 & 11,2 & $(14,3)$ & 10,6 & 6,3 & 168,3 & 92 \\
$1760-69$ & 133,7 & $(14,6)$ & $81,-$ & $(10,9)$ & 20,3 & 12,3 & $(14,6)$ & 11,1 & 6,7 & 165,1 & 90 \\
$1770-79$ & 171,4 & $(35,7)$ & 79,3 & $(20,8)$ & 20,7 & 9,6 & $(13,2)$ & 24,1 & 11,1 & 216,2 & 118 \\
$1780-89$ & 181,5 & $(50,1)$ & $78,-$ & $(27,6)$ & 20,5 & 8,8 & $(13,5)$ & 30,6 & 13,2 & 232,6 & 127 \\
$1790-99$ & 137,5 & $(20,5)$ & 84,4 & $(14,9)$ & 11,8 & 7,3 & $(9,1)$ & 13,6 & 8,3 & 162,9 & 87 \\
$1800-09$ & 132,6 & $(23,9)$ & 72,2 & $(18,-)$ & 16,9 & 9,2 & $(13,5)$ & 34,1 & 18,6 & 183,6 & 100 \\
$1810-19$ & 122,9 & $(20,2)$ & 80,7 & $(16,4)$ & 12,4 & 8,1 & $(10,8)$ & 17,1 & 11,2 & 152,4 & 84 \\
$1824-34$ & 149,4 & $(17,4)$ & 84,6 & $(11,6)$ & $10,-$ & 5,7 & $(7,-)$ & 17,2 & 9,7 & 176,6 & 96 \\
\hline
\end{tabular}

* Fanegas de centeno cultivadas en las rozas, incluidas en el total.

** Porcentaje de centeno cultivado en las rozas.

*** Porcentaje que representa el mijo sobre el centeno cultivado en las labranzas.

Fuente: Arquivo do Reino de Galicia (A Coruña), Monasterios, libros 125 y 347.

Las contabilidades se remontan a 1636, momento en el que el monasterio acomete una reordenación administrativa y crea esta granja, pero resulta muy dificultoso, o imposible en ocasiones, elaborar series homogéneas de carácter anual, debido a que los diezmos de Aranga ora se cobraban ora no por el monje granjero, y a que las rentas se vendían a veces en manojo, sin que conste el grano que hubiesen producido de haberse majado. No obstante, los datos que finalmente pudimos utilizar ponen de manifiesto algunos hechos de interés.

${ }^{49}$ En Castro de Rei la renta foral ascendía a 485 fanegas en 1650 y a 514 a principios del XIX, un aumento del 6 por cien en siglo y medio. 
De un lado el predominio abrumador del centeno dentro del sistema de cultivos a lo largo de todo el período analizado. Mas también los esfuerzos de los colonos por incrementar la producción de mijo, en particular desde 1690-99 a 1730-39, cuando las cosechas de centeno caen a niveles muy bajos. Esta vía de diversificación agraria no se consolida y entonces los campesinos echan mano de otro recurso, consistente en el cultivo del monte por el sistema de rozas: las cosechas de "pan avenoso" -comercializado a un precio inferior al centeno de las labranzas- se registran de modo esporádico en las décadas de 1690-99 y 1710-19, y se hacen regulares en la siguiente, aumentando sustancialmente las cantidades recogidas hasta la década de 1780-89. A partir de aquí inician un descenso tanto en términos absolutos como en el porcentaje que representan en el conjunto de todo el centeno cultivado.

En la etapa final del Antiguo Régimen, los campesinos de esta comarca parecen haber renunciado a la vía de la diversificación e intensificación agraria mediante la siembra de mijo (el maíz ni se menciona en los cuartos y quintos) y a través de la de carácter extensivo, consistente en las cavadas en el comunal. Aunque las cuentas no hacen referencia a ello, hay que colegir que la expansión del cultivo de las patatas en el último cuarto del XVIII y primer tercio del XIX contribuyó a resolver algunos problemas de las economías familiares, que abastecidas con nuevo tubérculo redujeron la producción de mijo y de centeno avenoso en las rozas, intensificando en cambio el aprovechamiento del esquilmo del abertal para fabricar abono ${ }^{50}$.

En realidad, los libros de la granja de Solme permiten realizar una reconstrucción aproximada de las fases por las que desde la primera mitad del XVII al momento de la exclaustración atraviesa la economía campesina de esta comarca interior. Hasta doblado el siglo XVII el componente silvo-pastoril de las economías familiares parece claro, a juzgar por el número de reses de todo tipo que en concepto de pago de luctuosas, de contratos de aparcería y de resultas de deudas entran cada año en poder del prior; pero un porcentaje elevado de los animales fallece por enfermedad, en las nevadas invernales o atacados por manadas de lobos, lo que denota que se trata de una ganadería extensiva, alimentada en montes que apenas se aprovechan para otra $\cos ^{51}$. Desde fines

${ }^{50}$ La expansión del cultivo de la patata en las parroquias próximas al dominio del priorato y pertenecientes a la diócesis de Mondoñedo está bien documentada en las valoraciones de curatos de fines del XVIII y comienzos del XIX, para la exención del noveno; Arquivo Diocesano de Mondoñedo, valoraciones de curatos (i.e. Parroquias de Labrada, Xestoso, etc.).

${ }^{51}$ Así en 1644, de 57 cabezas de vacuno mueren 14, y al año siguiente, de 47, fallecen 6. En el ganado menor de cabras y ovejas, las muertes son aún más abundantes y a veces espectaculares. En 1651, por ejemplo, sobre un recibo de 165 cabezas, desaparecen en el 
del XVII esta clase de ingresos ganaderos desaparece de las cuentas, y comienza el cultivo del monte por el sistema de rozas, es decir, la economía campesina se torna más dependiente de la producción de cereales y los lugareños hacen un uso agrario creciente, nuevo, del abertal, hasta que en el último cuarto del XVIII el cultivo de las patatas les permite reducir la extensión de las rozas $\mathrm{y}$ aprovechar ante todo el esquilmo para fabricar abono: otro uso agrario del monte, diferente al anterior.

\section{Los cambios agrarios y su repercusión en las rentas monásticas en las comarcas litorales y prelitorales}

En la Galicia occidental, desde las mariñas de Betanzos a las tierras miñotas la vigencia de muchos foros proporcionales a la cosecha y el dinamismo del sistema agrario repercutieron de modo muy positivo en los ingresos de los monasterios. Para un periodo de 84 años resulta de interés la serie de las rentas totales, de la casa central y de sus cinco prioratos o granjas, del monasterio de Monfero.

\begin{tabular}{crrrrrrrrrrrr}
\multicolumn{10}{c}{ Cuadro - Ingresos globales de cereales de Monfero. Media anual en hls } \\
\hline Años & \multicolumn{1}{c}{ Trigo } & \multicolumn{1}{c}{$\%$} & Centeno & \multicolumn{1}{c}{$\%$} & Mijo & \multicolumn{1}{c}{$\%$} & Maíz & \multicolumn{1}{c}{$\%$} & Avena & $\%$ & Total & Índice \\
\hline $1683-99$ & 220,5 & 9,9 & $1.433,9$ & 64,3 & 255,4 & 11,5 & 209,8 & 9,4 & 108,9 & 4,9 & $2.228,5$ & 100 \\
$1698-1709$ & 190,2 & 8,7 & $1.454,6$ & 66,4 & 238,9 & 10,9 & 214,7 & 9,8 & 91,9 & 4,2 & $2.190,3$ & 98 \\
$1710-20$ & 224,5 & 10,1 & $1.429,3$ & 64,1 & 201,8 & 9,1 & 286,1 & 12,8 & 86,6 & 3,9 & $2.228,3$ & 100 \\
$1721-29$ & 172,4 & $8,-$ & $1.342,3$ & 61,7 & 235,4 & 10,8 & 374,3 & 17,2 & $49,-$ & 2,3 & $2.175,2$ & 98 \\
$1730-40$ & $198,-$ & 8,2 & $1.509,4$ & 62,4 & 235,7 & 9,8 & 406,5 & 16,8 & 67,4 & 2,8 & $2.417,-$ & 108 \\
$1741-49$ & 136,9 & 5,1 & $1.686,9$ & 63,2 & 261,1 & 9,8 & 525 & 19,6 & 60,4 & 2,3 & $2.670,3$ & 120 \\
$1750-58$ & 174,7 & 6,9 & $1.630,5$ & 64,5 & $174,-$ & 6,9 & 484,9 & 19,2 & 63,6 & 2,5 & $2.527,7$ & 113 \\
$1759-66$ & 187,2 & 6,7 & $1.700,3$ & 60,8 & 201,5 & 7,2 & 621,9 & 22,3 & 82,9 & $3,-$ & $2.793,8$ & 125 \\
\hline
\end{tabular}

Fuente: Arquivo do Reino de Galicia, Monasterios, libro 12 de Monfero.

Se trata de un cenobio de mucha menos entidad que Oseira, cuyas rentas en cereales multiplicaban por 2,5 las de Monfero a mediados del XVIII, siendo aun mucho mayor la distancia entre los ingresos vitícolas. A la vez, las rentas de Monfero, aunque dominadas por el centeno, eran más diversificadas

invierno 136. Archivo del Reino de Galicia, Monasterios, libro 125, cuentas de abril de 1645 , 1646 y 1652, con otros muchos ejemplos. Sobre el componente "silvo-pastoril" de las economías campesinas del litoral cantábrico y atlántico, antes de la entrada del maíz, vid. Luis $\mathrm{M}^{\mathrm{a}}$ Bilbao y Emiliano Fernández de Pinedo, "La producción agrícola en el País Vasco Peninsular, 1537-1850. Tendencia general y contrastes comarcales”, Sociedad de Estudios Vascos, 1984, pp. 83-196, y José Manuel Pérez García, "Niveles y transformaciones de la ganadería de Galicia en el siglo XVII”, Cuadernos de Estudios Gallegos, XXXIII, 1982, pp. 87-177. 
y sobre todo más dinámicas que las del gran cenobio de Ourense: si las de éste permanecieron estancadas entre 1680 y 1760, las de Monfero aumentaron un 25 por cien, situándose el momento de la expansión en la década de 1730 . No se aprecian en el período analizado -único para el que existe información global de la casa central y los prioratos- cambios radicales en lo referido a la importancia porcentual de los cereales de invierno y primavera. Los primeros mantienen, aun doblado el siglo XVIII, una clara hegemonía, mientras que hasta la década de 1720 las entradas de mijo superan a las de maíz, planta que avanza con cierta lentitud, aunque las cosechas se triplican entre 1683-94 y 1759-66, sin amenazar la posición de los cereales de invierno, y en especial la del centeno, cuya producción crece un 18,5 por cien en esos 84 años.

Pero las cifras globales son el resultado de la suma de rentas cobradas en comarcas con sistemas de cultivos muy distintos. El gran priorato de Labrada estaba situado en el interior montañoso, en donde el maíz no hizo acto de presencia; Callobre, Saa y Carantoña radicaban en las mariñas, mientras la abadía -que ingresaba directamente las rentas de la panera- y Ambroa se situaban en tierras de transición. De este modo, entre las rentas de la panera, el mijo sólo a partir de 1780/89 se convierte en un cultivo residual, sin que el maíz iguale la importancia del centeno. Al contrario, en el priorato mariñán de Callobre el maíz constituía a fines del XVII el cereal que mayores rentas de cuartos y quintos proporcionaba, reforzando su hegemonía, y a la vez el incremento de los ingresos, en la centuria siguiente ${ }^{52}$ :

Cuadro - Cambios en la composición de los cultivos cerealeros en el priorato de Callobre, sufragáneo de Monfero, entre fines del XVII y comienzos del XIX. Medias anuales en hls

\begin{tabular}{crrrccccccc}
\hline Años & \multicolumn{1}{c}{ Trigo } & \multicolumn{1}{c}{$\%$} & Centeno & $\%$ & Mijo & $\%$ & Maíz & $\%$ & Total & Índice \\
\hline $1691-99$ & 25,8 & 18,3 & $34,-$ & 24,2 & 6,8 & 4,8 & $74,-$ & 52,6 & 140,6 & 100 \\
$1750-59$ & $92,--$ & 6,2 & 63,6 & $33,-$ & - & - & 117,1 & 60,8 & 192,7 & 137 \\
$1810-19$ & 7,8 & 4,3 & 41,6 & $23,-$ & - & - & 131,8 & 72,7 & 181,2 & 129 \\
\hline
\end{tabular}

Fuente: Arquivo do Reino de Galicia, Monasterios, Monfero, leg. 281.

En el caso del poderoso monasterio de Sobrado, con Oseira el de rentas más cuantiosas dentro del Císter gallego, la evolución contrastada de los ingresos de las administraciones radicadas en comarcas interiores productoras de centeno y en las de las mariñas y litoral resulta patente:

${ }^{52}$ Vid. datos más amplios de este priorato en Pegerto Saavedra, Das casas de morada, op.cit., p. 203. 
Cuadro - Trayectoria de los ingresos cerealeros de la panera de Sobrado y de los prioratos mariñáns de las Cascas y San Martiño do Porto. Medias anuales en hls

\begin{tabular}{ccccccc}
\hline Años & Panera de Sobrado & Índice & Las Cascas & Índice & San Martiño do Porto & Índice \\
\hline $1620-49$ & $2.334,6$ & 100 & 269,5 & 100 & 81,3 & 100 \\
$1650-99$ & $2.337,9$ & 100 & 341,1 & 127 & $114,-$ & 140 \\
$1700-49$ & $2.346,9$ & 101 & 411,9 & 153 & 155,4 & 191 \\
$1750-99$ & $2.291,-$ & 98 & 444,5 & 165 & 236,8 & 291 \\
$1800-34$ & $2.251,6$ & 96 & 440,7 & 164 & 234,5 & 288 \\
\hline
\end{tabular}

Fuente: Arquivo do Reino de Galicia (A Coruña), Monasterios, Sobrado, libros 19, 21, 237, 238, 123 y 132.

La panera monástica mantiene unos ingresos constantes, prácticamente en su totalidad de centeno, a lo largo de más de dos siglos. La estabilidad deriva del peso de la renta foral de carácter fijo - un 95 por cien del total de entradas-, y a la vez de la falta de transformación de un sistema agrario del que están ausentes hasta la etapa final del Antiguo Régimen los cereales de primavera. Al contrario, en los prioratos de la mariña, la vigencia de foros al cuarto y al quinto y la percepción de algunos diezmos conllevaban una vinculación orgánica entre rentas y producción, y ésta creció de modo muy notable, sobre todo a raíz de la expansión del maíz, que en la larga duración transforma notablemente un sistema agrario en principio dominado por el trigo y el centeno. Son sobre todo las rentas proporcionales las responsables del incremento de los ingresos, de ahí que en San Martiño do Porto, en donde los foros estaban estipulados al cuarto o al quinto, y rara vez en cantidades fijas en especie -pues éstas se fueron convirtiendo a dinero-, las rentas casi se tripliquen, en tanto en las Cascas, con una mayor presencia de las rentas fijas, el incremento es menor, aunque significativo.

Cuadro - Composición de las rentas proporcionales en las Cascas y en San Martiño do Porto. Medias anuales en hls

\begin{tabular}{crrccrrrrr}
\hline \multicolumn{7}{c}{ Las Cascas } \\
\hline Años & Trigo & \multicolumn{1}{c}{$\%$} & Centeno & $\%$ & \multicolumn{1}{c}{ Mijo } & \multicolumn{1}{c}{$\%$} & Maíz & $\%$ & Total \\
\hline $1620-29$ & 7,4 & 28,9 & 15,6 & 60,9 & 2,6 & 10,2 & - & - & 25,6 \\
$1630-39$ & 6,3 & 18,4 & 21,8 & 63,5 & 6,2 & 18,1 & - & - & 34,3 \\
$1640-49$ & 9,2 & 16,5 & 32,3 & $58,-$ & 12,1 & 21,7 & 2,1 & 3,8 & 55,7 \\
$1650-59$ & $9,-$ & 14,4 & 36,8 & $59,-$ & 11,4 & 18,3 & 5,2 & 8,3 & 62,4 \\
$1660-69$ & 5,7 & 9,5 & 35,1 & 58,2 & 8,5 & 14,1 & $11,-$ & 18,2 & 60,3 \\
$1670-79$ & 15,3 & 20,1 & 29,7 & 39,1 & 11,9 & 15,6 & 19,1 & 25,2 & 76 \\
$1680-89$ & 7,8 & 9,5 & 35,5 & 43,3 & 8,2 & $10,-$ & 30,4 & 37,1 & 81,9 \\
$1690-99$ & 7,6 & 9,9 & 35,6 & 46,4 & 4,9 & 6,4 & 28,6 & 37,3 & 76,7 \\
$1700-09$ & 14,9 & 15,8 & 40,2 & 42,6 & 10,3 & $11,-$ & 28,9 & 30,6 & 94,3 \\
$1710-19$ & 13,4 & 12,5 & 45,9 & 42,9 & 8,9 & 8,3 & 38,7 & 36,2 & 106,9 \\
$1720-29$ & 19,3 & 12,4 & 69,8 & 45,1 & 11,8 & 7,6 & 54,2 & 34,9 & 155,1 \\
$1730-39$ & 14,9 & 9,2 & 68,9 & 42,4 & 5,2 & 3,2 & 73,5 & 45,2 & 162,5 \\
$1740-49$ & 14,5 & 9,7 & 68,9 & $46,-$ & 3,6 & 2,4 & 62,7 & 41,9 & 149,7 \\
$1750-59$ & 11,5 & 8,3 & 69,9 & 50,3 & 3,7 & 2,7 & 53,7 & 38,7 & 138,8 \\
$1760-69$ & $10,-$ & 6,6 & 67,8 & 45,1 & 3,7 & 2,5 & 68,9 & 45,8 & 150,4 \\
\hline
\end{tabular}




\begin{tabular}{|c|c|c|c|c|c|c|c|c|c|}
\hline \multicolumn{10}{|c|}{ Las Cascas } \\
\hline Años & Trigo & $\%$ & Centeno & $\%$ & Mijo & $\%$ & Maíz & $\%$ & Total \\
\hline $1770-79$ & 18,5 & 10,5 & $70,-$ & 39,9 & 3,5 & $2,-$ & 83,4 & 47,6 & 175,4 \\
\hline $1780-89$ & 21,5 & 9,9 & 99,6 & 45,8 & 2,4 & 1,1 & 94,1 & 43,2 & 217,6 \\
\hline $1790-99$ & 12,5 & 9,5 & 50 & 37,8 & 0,7 & 0,5 & 68,9 & 52,2 & 132,1 \\
\hline 1800-09 & 8,2 & 7,5 & 35,8 & 32,9 & 0,7 & 0,6 & 64,2 & $59,-$ & 108,9 \\
\hline 1810-19 & 16,7 & 12,2 & 50,7 & 37,1 & - & - & 69,2 & 50,7 & 136,6 \\
\hline 1824-34 & 28 & 19,1 & 47,7 & 32,6 & - & - & 70,6 & 48,3 & 146,3 \\
\hline \multicolumn{10}{|c|}{ San Martiño do Porto } \\
\hline Años & Trigo & $\%$ & Centeno & $\%$ & Mijo & $\%$ & Maíz & $\%$ & Total \\
\hline $1620-29$ & - & - & - & - & - & - & - & - & - \\
\hline $1630-39$ & - & - & - & - & - & - & - & - & - \\
\hline $1640-49$ & 20 & 24,6 & 39,7 & 48,8 & 7,7 & 9,5 & 13,9 & 17,1 & 81,3 \\
\hline $1650-59$ & 18,2 & 23,5 & 36,8 & 47,5 & 11,9 & 15,4 & 10,5 & 13,6 & 77,4 \\
\hline $1660-69$ & 18,2 & 15,9 & 36,8 & 32,2 & 6,9 & $6,-$ & 52,4 & 45,8 & 114,3 \\
\hline $1670-79$ & 8,7 & 9,3 & 28,1 & $30,-$ & 4,2 & 4,5 & 52,7 & 56,2 & 93,7 \\
\hline $1680-89$ & 6,8 & 4,7 & 27,4 & 18,8 & 4,4 & $3,-$ & 107,2 & 73,5 & 145,8 \\
\hline $1690-99$ & 8,1 & 5,8 & 32,7 & 23,6 & 5,3 & 3,8 & 92,6 & 66,8 & 138,7 \\
\hline 1700-09 & 6,9 & 5,8 & 36,3 & 30,3 & 8,1 & 6,8 & 68,4 & 57,1 & 119,7 \\
\hline 1710-19 & 6,1 & 3,8 & 28,5 & 17,8 & 7,2 & 4,5 & 118,3 & 73,9 & 160,1 \\
\hline $1720-29$ & 5,3 & 3,1 & 30,8 & 18,3 & 5,6 & 3,3 & 127,1 & 75,3 & 168,8 \\
\hline 1730-39 & 5,2 & 3,1 & 30,3 & 18,2 & 3,4 & $2,-$ & 127,9 & 76,7 & 166,8 \\
\hline $1740-49$ & 6,5 & $4,-$ & 24,3 & $15,-$ & 1,5 & 0,9 & 129,3 & $80,-$ & 161,6 \\
\hline $1750-59$ & 6,4 & $3,-$ & 21,1 & $10,-$ & 0,8 & 0,4 & 182,9 & 86,6 & 211,2 \\
\hline $1760-69$ & 5,9 & 2,4 & 27,3 & $11,-$ & 0,6 & 0,2 & 215,1 & 86,4 & 248,9 \\
\hline $1770-79$ & 8,7 & 4,2 & 19,7 & 9,4 & - & - & 181,1 & 86,4 & 209,5 \\
\hline $1780-89$ & 11,6 & 4,3 & 13,2 & 4,8 & - & - & 246,9 & 90,9 & 271,7 \\
\hline 1790-99 & 8,7 & 3,6 & 7,7 & 3,2 & - & - & 226,1 & 93,2 & 242,5 \\
\hline 1800-09 & 13,4 & 6,1 & 13,2 & 6,1 & - & - & 191,9 & 87,8 & 218,5 \\
\hline 1810-19 & 18,1 & $8,-$ & $14,-$ & 6,2 & - & - & 193,4 & 85,8 & 225,5 \\
\hline 1824-34 & 12,7 & 5,2 & 4,4 & 1,8 & - & - & 226,7 & $93,-$ & 243,8 \\
\hline
\end{tabular}

Fuente: Arquivo do Reino de Galicia, Monasterios, libros 237 y 238 (Las Cascas) y 123 y 132 (San Martiño do Porto).

Se trata de dos prioratos próximos, en los cuales sin embargo las transformaciones no tienen la misma intensidad, lo que probablemente deriva de las condiciones edafológicas, sin que quepa descartar el peso de las rentas fijas de centeno y trigo en las Cascas como factor que contribuye a mantener esos cultivos. El maíz avanza aquí con lentitud y en varias fases: una primera expansión desde 1640/49 a 1680/89; y luego una fase de estabilidad hasta doblado el siglo XVIII; sólo a fines de esta centuria las cosechas de la planta americana superan en volumen a las de centeno y trigo. Es obvio que la producción y las rentas aumentan, pero ello no se debe sólo al maíz, sino también al centeno hasta 1780/89, una década caracterizada, como es sabido, por excelentes cosechas. Desde la primera mitad del XVII hasta vísperas de la exclaustración, las rentas proporcionales se multiplicaron por cuatro, lo que le permitió a los granjeros comercializar cantidades crecientes de cereales: de unas 294,5 fanegas 
al año en 1620-49 se pasa a 541 en 1750-99; de estas 541 eran de maíz 72,6, el 13,4 por cien (o el 17 si el cálculo se hace en hls, por la mayor cabida de la fanega colmada, de 98,8 litros frente a los 76 de la rasa).

En San Martiño do Porto, en donde las rentas fijas eran escasísimas, las transformaciones agrarias son más tempranas y radicales. La situación inicial es parecida a de las Cascas, pero el maíz avanza con más rapidez hasta representar de dos tercios a tres cuartas partes de la cosecha en las últimas décadas del XVII, para convertirse en la etapa final del Antiguo Régimen en el cereal que domina por completo las labranzas. De una situación dominada por el centeno y el trigo -y el vino, como se verá-, se pasa a otra en la que la planta de primavera casi monopoliza el sistema de cultivos, al menos en lo tocante a los cereales. Los monjes granjeros se beneficiaron ampliamente de estos cambios, pues entre 1640-49 y 1824-34 sus rentas se triplicaron: si cayeron casi a la mitad las de trigo, un 90 por cien las de centeno, y desaparecieron las de mijo -de entrada poco relevantes-, las de maíz en cambio se multiplicaron por $16^{53}$.

También en el caso de los monasterios de la Galicia tudense queda patente la estrecha relación entre la estructura cambiante de las entradas de cereales y las transformaciones radicales del sistema agrario, dada la vinculación orgánica que a través de los cuartos y quintos -denominados "raciones" en la contabilidad de Oia- y diezmos se establecía entre ingresos y producción, en unas comarcas con un sistema de cultivos diversificado y dinámico:

Cuadro - Ingresos de la panera de A Franqueira. Medias anuales en hls

\begin{tabular}{cccccrrr}
\hline Años & Centeno & \multicolumn{1}{c}{$\%$} & \multicolumn{1}{c}{ Mijo } & \multicolumn{1}{c}{$\%$} & \multicolumn{1}{c}{ Maíz } & \multicolumn{1}{c}{$\%$} & Total \\
\hline $1623-1647$ & 137,3 & 43,3 & 179,2 & 56,5 & 0,6 & 0,2 & $317,-$ \\
$1648-1674$ & 138,5 & 35,5 & 152,9 & 39,2 & 98,4 & 25,3 & 389,8 \\
$1675-1698$ & 92,8 & 25,8 & 103,2 & 28,7 & 163,8 & 45,5 & 359,8 \\
$1699-1724$ & 73,4 & $26,-$ & 78,3 & 27,8 & 130,5 & 46,2 & 282,2 \\
$1725-1750$ & $83,-$ & 27,8 & 76,1 & 25,5 & 139,5 & 46,7 & 298,6 \\
$1751-1767$ & 123,7 & 32,6 & 117,5 & 30,9 & 138,6 & 36,5 & 379,8 \\
$1800-1804$ & 79,2 & 28 & $63,-$ & 22,2 & 141,2 & 49,8 & 283,4 \\
$1830-1834$ & 67,1 & 28,7 & 49,3 & 21,1 & 117,3 & 50,2 & 233,7 \\
\hline
\end{tabular}

Fuente: Archivo Histórico Nacional (Madrid), Clero, libros 10.051, 10.052, 10.054 y 10.055.

${ }^{53}$ Resulta claro, en todo caso, la necesidad de estudiar la transformación de un sistema agrario en la larga duración, según la revela la trayectoria de los diversos cultivos en los prioratos de las Cascas y Porto. En un estudio clásico, el profesor José Manuel Pérez García demostró en ciertas comarcas de las Rías Baixas que el maíz se convirtió en pocas décadas en el cereal básico en la alimentación campesina; vid., de este autor, “Aproximación al estudio de la penetración del maíz en Galicia”, en Antonio Eiras Roel et alii, La historia social de Galicia en sus fuentes de protocolos, Universidad de Santiago de Compostela, 1981, pp. 117-159. 
De la observación de los datos del cuadro es posible advertir una situación hasta ahora poco conocida: el mijo constituye el cereal que más abunda en la panera del monasterio hasta la década de 1660, sacando en algunos trienios grandes ventajas al centeno (superiores al 40 por cien, por ejemplo en 1639-41 y en 1642-44). Esto es lo que, antes de nada, conviene destacar, pues las cantidades sólo informan de la estructura de los ingresos de este pequeño cenobio -en realidad una presidencia- ${ }^{54}$, y no de su evolución global, afectada por el recurso intermitente a arriendos de partidos, por lo que la serie no permite conocer la trayectoria de las rentas totales en cereales. La fuerte posición del mijo en el sistema agrario del Miño medio puede comprobarse aún mejor a partir de series de diezmos en especie del mismo cenobio, que se remontan a la década de 1580:

Cuadro - Diezmos y primicias del monasterio de Franqueira en las parroquias de Cebreiro, A Franqueira y Huma. Medias anuales en hls

\begin{tabular}{cccccrrrrr}
\hline Años & Trigo & \multicolumn{1}{c}{$\%$} & Centeno & \multicolumn{1}{c}{$\%$} & \multicolumn{1}{c}{ Mijo } & \multicolumn{1}{c}{$\%$} & Maíz & $\%$ & Total \\
\hline $1585-89$ & 0,5 & 0,4 & 46,8 & $34,-$ & 90,2 & 65,6 & - & - & 137,5 \\
$1590-94$ & 2,3 & 1,5 & 58,5 & 38,2 & 92,4 & 60,3 & - & - & 153,2 \\
$1595-99$ & 3,4 & 2,4 & 38,8 & 27,1 & 100,9 & 70,5 & - & - & 143,1 \\
$1600-04$ & 4,2 & 3,7 & 46,6 & 40,6 & 63,8 & 55,7 & - & - & 114,6 \\
$1605-09$ & 4,5 & 2,7 & 52,4 & 31,8 & 107,7 & 65,4 & - & - & 164,6 \\
$1635-39$ & 3,2 & 2,6 & 41,2 & 33,8 & 77,5 & 63,6 & - & - & 121,9 \\
$1640-44$ & 3,8 & 2,6 & 39,3 & 26,6 & 58,8 & 39,7 & 46,1 & 31,1 & $148,-$ \\
$1640-49$ & 3,9 & 2,1 & 55,3 & 29,8 & 58,7 & 31,7 & 67,5 & 36,4 & 185,4 \\
$1750-54$ & 3,4 & 1,7 & 22,4 & 11,5 & 29,6 & 15,2 & 139,2 & 71,5 & 194,6 \\
$1780-84$ & 1,7 & 0,8 & 28,6 & 13,5 & 23,9 & 11,3 & 157,1 & 74,3 & 211,3 \\
$1824-34$ & 0,6 & 0,5 & 23,9 & $18,-$ & 13,2 & $10,-$ & 94,8 & 71,5 & 132,5 \\
\hline
\end{tabular}

Fuente: Archivo Histórico Nacional, Clero, libros 10.051 y 10.054.

Hasta mediados de la década de 1630 el mijo parece representar entre un 60 y un 70 por cien de la producción cerealera, una proporción quizá algo superior a la real, al pagar los campesinos en este cereal la primicia. Pero el hecho mismo de que esa carga estuviese fijada en mijo pone de manifiesto su condición de cultivo más común, quizá ya en la Baja Edad Media. En todo caso, desde 1585 a 1639 la estructura de los ingresos por diezmos, y por tanto de los cultivos, permanece estable, sin que se noten tampoco grandes oscilaciones en los niveles de producción. El mijo no incrementa su importancia en ese medio siglo largo,

${ }^{54}$ El número de monjes de la comunidad oscilaba entre tres y seis, según las épocas, y sus entradas en numerario equivalían en 1780-89 al 5,5 por cien de las de Oseira o Sobrado. 
porque partía ya de una posición muy ventajosa con respecto a los cereales de invierno, adelantando en cierto modo lo que después sucederá con el maíz ${ }^{55}$.

Por lo que respecta a los ingresos totales de la panera del monasterio de Franqueira conviene destacar antes de nada los cambios en su composición con la aparición del maíz a fines de la década de 1630 (62 celemines o ferrados se computan en el trienio 1636-38), y su rápido avance hasta 1662; su progresión no se detiene ahí, pero luego es más lenta y fluctuante. Es realmente el maíz el responsable del incremento de las entradas -y por tanto de la producción- desde 1641 hasta 1665. Con posterioridad a esta fecha, y a veces debido precisamente a la abundancia de granos ${ }^{56}$, los monjes optaron en ocasiones por el arriendo de las rentas de algunas parroquias, de modo que las series son entonces más indicativas de la estructura de los cultivos cerealeros que de la evolución global de la producción, y al respecto cabe destacar la importancia creciente, medida en términos porcentuales, del maíz, pero también la resistencia del centeno y, lo que nos parece más novedoso, del mijo, que aunque cada vez de modo más residual, continuaba cultivándose y consumiéndose en vísperas de la exclaustración. Es cierto que en la masa decimal y de las primicias el viejo cereal sólo representa en 1824-34 el 10 por cien, mientras en los ingresos globales de la panera supone el 21,1 , por la rigidez de las rentas forales; cabe admitir incluso que, como el diezmo se percibe con la primicia (una carga fija), el mijo no llegaba a alcanzar la décima parte de la producción. Pero no cabe duda de que una parte se ingresaba y consumía en especie, pues en 1824-34 las ventas suponen de promedio sólo un 50 por cien del recibo ${ }^{57}$.

En resumen, lo novedoso de la situación, con respecto a lo conocido hasta ahora es, como ya quedó indicado, el gran peso que los cereales de primavera tenían en el sistema agrario del Miño medio mucho antes de la introducción del maíz, y también la resistencia del mijo frente al cereal americano, que ni

${ }^{55}$ El predominio del mijo dentro del sistema cerealero parece un rasgo de la Galicia tudense, a juzgar por los datos del priorato del Rosal, sufragáneo de Oia. Para la Edad Media vid., Ermelindo Portela Silva, La región del obispado de Tuy en los siglos XII al XV. Una sociedad en la expansión y en la crisis, Santiago, 1975, y María del C. Sánchez Carrera, El Bajo Miño en el siglo XV: el espacio y los hombres, A Coruña, Fundación Pedro Barrié de la Maza, 1997.

${ }^{56}$ Así en las cuentas rendidas en abril de 1671, el padre panero advierte que se arrendaron los partidos de Huma y Salvaterra "por haber mucha abundancia de granos en la tierra y venderse muy mal las del monasterio", Archivo Histórico Nacional, Clero, libro 10.051, cuentas de abril de 1671 .

${ }^{57}$ Vid., últimamente, María Seijas Montero, “Aproximación a la actividad económica del monasterio cisterciense de Santa María de Franqueira en la época Moderna”, Galicia monástica. Estudos en lembranza da profesora María José Portela Silva, ed. de Raquel Casal et alii, Universidade de Santiago de Compostela, 2009, p. 257. 
siquiera en el curso de dos siglos es capaz de hacerle desaparecer. A principios del XIX el monasterio de A Franqueira continúa ingresando diezmos y rentas forales de mijo $\mathrm{y}$, aunque algunas entradas son meramente teóricas -cobradas en dinero-, otras son percibidas en la propia especie. En cambio en el Bajo Miño, el mijo, también muy difundido hacia 1600, desapareció o casi en algunas comarcas ya antes de 1700 . Así lo acreditan las cuentas de la casa central y de los prioratos de Oia, y para mediados del XVIII el catastro de Ensenada ${ }^{58}$.

Al igual que en A Franqueira, las contabilidades del monasterio de Oia no permiten elaborar series homogéneas de ingresos en especie, debido a la reordenación de partidos y al recurso periódico a los arriendos de algunos de ellos, pero aun así, los datos de la panera dejan ver la estrecha relación entre la estructura cambiante de los ingresos cerealeros y las transformaciones radicales del sistema agrario:

Cuadro - Raciones y diezmos percibidos por la panera del monasterio de Oia.

Medias anuales en hls

\begin{tabular}{crrrrrrrrrrr}
\hline Años & Trigo & \multicolumn{1}{c}{$\%$} & \multicolumn{1}{c}{ Centeno } & $\%$ & Mijo & $\%$ & Maíz & $\%$ & Cebada & \multicolumn{1}{c}{$\%$} & Total \\
\hline $1617-19$ & 47,1 & 11,2 & 197,5 & $47,-$ & 130,5 & $31,-$ & - & - & 45,3 & 10,8 & 420,4 \\
$1620-24$ & 63,4 & 13,9 & 241,5 & 52,8 & 116,5 & 25,5 & - & - & 35,5 & 7,8 & 456,9 \\
$1642-49$ & 40,8 & 7,1 & 163,8 & 28,5 & - & - & 294,6 & 51,2 & 75,9 & 13,2 & 575,1 \\
$1650-54$ & 33,9 & 6,5 & 170,8 & 32,9 & - & - & 270,2 & $52,-$ & 44,9 & 8,6 & 519,8 \\
$1655-59$ & 34,3 & $6,-$ & 150,6 & 26,5 & - & - & 332,1 & 58,4 & 51,5 & 9,1 & 568,5 \\
$1660-64$ & 31,5 & 5,9 & 106,6 & $20,-$ & - & - & 355,2 & 66,8 & 38,9 & 7,3 & 532,2 \\
$1665-69$ & 46,1 & 8,7 & 111,3 & $21,-$ & - & - & 343,2 & 64,7 & 29,8 & 5,6 & 530,4 \\
$1670-74$ & 40,3 & 7,3 & 146,1 & 26,5 & - & - & 357,1 & 64,7 & 8,1 & 1,5 & 551,6 \\
$1675-79$ & $27,-$ & 5,6 & 81,9 & 16,9 & - & - & 357,7 & 74,1 & 16,4 & 3,4 & $483,-$ \\
$1680-84$ & 22,6 & 4,4 & 97,4 & 18,9 & - & - & 357,7 & 69,6 & 36,3 & 7,1 & $514,-$ \\
$1685-89$ & 12,1 & 2,3 & 101,7 & 19,7 & - & - & 366,2 & 70,9 & 36,9 & 7,1 & 516,9 \\
$1690-94$ & 6,9 & 1,3 & 99,6 & 18,1 & - & - & 414,9 & 75,4 & 28,7 & 5,2 & 550,1 \\
$1695-99$ & 5,5 & 0,9 & 109,5 & 17,1 & - & - & 502,3 & 78,2 & 24,6 & 3,8 & 641,9 \\
\hline
\end{tabular}

Fuente: Archivo Histórico Nacional, Clero, libro 10.231.

En un sistema de cultivos dominado ligeramente a comienzos del XVII por los cereales de invierno, el maíz irrumpe de súbito y desplaza por completo al mijo, arrinconando asimismo al trigo y a la cebada y reduciendo en más de un 50 por cien la proporción que alcanzaba el centeno ${ }^{59}$. En períodos cortos,

${ }^{58}$ En el Bajo del Miño, el mijo está casi ausente del sistema de cultivos a mediados del XVIII. Cf. José Manuel Pérez García, "En los límites del virtuosismo agrario tradicional", op. cit., pp. 221-245.

${ }^{59}$ El padre panero advierte en las cuentas de 1644, correspondientes a la cosecha del anterior, que en los 18 años pasados los vecinos de Pedornes habían pagado una renta fija, y "en este tiempo del arriendo se introduxo sembrar millo maíz, y este año se cogieron de diezmo y raçiones [cuartos y quintos] (...) doscientos ochenta bucios, de que me hago cargo, advirtiendo para los venideros que, por más diligencia que se hicieron para cobrarlo, ocultaron mucha cantidad, 
la serie no representa con fidelidad la verdadera importancia del maíz -ni de la producción global-, por cuanto el monasterio realiza ajustes con los campesinos, que va actualizando al paso de los años, conforme aumentan las cosechas del cereal americano ${ }^{60}$. Así, desde 1670 a 1688 los colonos pagaron 282 bucios por cuartos, quintos y diezmos; en 1689 se les aumentó la cantidad a 315,3, y en 1691 a 330, para fiscalizar las roturaciones; en el último quinquenio observado el padre panero cobró de acuerdo con la producción real, ingresando en 1696 580 bucios. Se trata, como puede verse, de un caso diferente al de A Franqueira, en donde el mijo alcanzaba un mayor peso porcentual antes de maíz y resistía mejor la competencia de éste. Al respecto, sólo un estudio de las condiciones edafológicas de cada comarca podrá ofrecer explicación satisfactoria de estos contrastes, nada extraños en una época en la que la agricultura variaba de aldea a aldea en la misma parroquia.

Incluso las rentas forales estipuladas en cantidades fijas por la comunidad monástica de Oia mostraron una gran sensibilidad a los tipos de cultivos. En 1630 se componían en un 13,4 por cien de trigo, un 54,2 de centeno, un 28,7 de mijo y un 3,7 de cebada, mientras en 1702 los porcentajes eran, por el mismo orden, del 6,4,31,7,1,9 y 3,2, ocupando ahora el maíz la primera posición con el 56,8, por eso en los ingresos generales de la panera el maíz aparece en todo el XVIII como el cereal mayoritario: 552,6 bucios de promedio en 1702-1706 , frente a 402,8 de centeno, y 537,6 frente a 374,6 , por el mismo orden, en 1780-84, cuando la comunidad se veía obligada año tras año a comprar trigo para su propio consumo, y a admitir cantidades de maíz en pago de rentas concertadas en aquel cereal.

El mijo desaparece con rapidez de las rentas proporcionales a la cosecha -“raciones" y diezmos- de la panera del monasterio de Oia, aunque se conserva como carga fija, ocupando, eso sí, una posición cada vez más residual. Otro tanto ocurre en prioratos radicados en las proximidades del Bajo Miño, como el de O Rosal o en la granja de Silva: en 1619-23, el mijo representaba en

y haciendo cala y cata se hallaron casas que no habían pagado la mitad de lo que debían. Ellos tratan de reducirlo como estaba a renta sabida...". Archivo Histórico Nacional, Clero, libro 10.231, a. 1644 .

${ }^{60}$ Los convenios fijaban la cantidad a pagar de maíz, contribuyendo los otros cereales en proporción a la producción real de cada año, por eso en las cuentas de 1655 el padre panero señala que "de malicia [los colonos] dejaron de sembrar algunas heredades que les tocaba ese año el sembrar de centeno y trigo, y las sembraron de maíz atendiendo que no habían de pagar más de lo que tenían concertado de maíz, y así faltó al centeno; se le racionaron [cuartearon y quintearon] aquellas heredades...". Archivo Histórico Nacional, Clero, libro 10.231, a. 1655; el bucio equivale a 1,5 fanegas, y la fanega a 63,44 ó 84,56 litros, según sea rasa o colmada (maíz y cebada). 
O Rosal, el 52,4 por cien de las rentas totales y el 62,3 por cien de las proporcionales; en 1763, su posición la ocupaba el maíz, y con ventaja. En la granja de Silva, situada en territorio portugués (en Valença y Vila Nova de Cerveira), el mijo suponía en 1610-19 el 57,4 por cien de las rentas proporcionales (y el 49,3 de las globales); el maíz se menciona aquí por primera vez en 1638, y en la década de 1670 había desplazado por completo al viejo cereal de primavera, que ya no aparece en las cuentas de los priores ${ }^{61}$. Parece, en cualquier caso, que a ambos lados del Miño el maíz se introduce unas décadas más tarde que en el Baixo Mondego, en donde está documentado a fines del $\mathrm{XVI}^{62}$.

\section{Un apunte final sobre la economía vitícola}

La historiografía ha venido asociando los monasterios, y en particular los cistercienses, con la expansión del cultivo de la vid a lo largo de los valles fluviales de Ourense y del sur de Lugo, en donde radicaban varias comunidades y numerosas granjas. Los tumbos, apeos y libros de foros acreditan que en los siglos centrales de la Edad Media, y también en el XV y XVI, diversos cenobios impulsaron decididamente las plantaciones de vides, con vistas a obtener rentas para su consumo ordinario y también para destinar al mercado ${ }^{63}$. Pero si en los siglos XVII y XVIII el sistema agrario de la mayor parte de Galicia se transformó profundamente, debido a los múltiples cambios encadenados que supuso la expansión del maíz en las comarcas litorales y en los valles fluviales, o en las de clima más duro del interior la tardía difusión del cultivo de la patata -poco

${ }^{61}$ Archivo Histórico Nacional, Clero, libro 10.277, con cuentas de las diversas granjas de Oia de la primera mitad del XVII; libro 10.231 (cuentas de o Rosal), y libros 10.227 y 10.226 (cuentas de la granja de Silva, en el primero en medidas -alqueires- y monedas portuguesas y en el segundo en ferrados y reales). De esta granja viene ocupándose la medievalista portuguesa Ana Paula Leite Rodrigues, quien en junio de 2010 presentó en el Departamento de Historia Medieval y Moderna de la Universidad de Santiago de Compostela un trabajo para la obtención del DEA sobre "O Tombo da Granja da Silva (1560/1565). Bases para uma análise da propiedade transfronteiriça do Mosteiro de Santa Maria de Oia”.

${ }^{62}$ Vid., especialmente, António de Oliveira, A vida económica e social de Coimbra de 1537 a 1640, Coimbra, Facultade de Filosofia e Letras, 1972, vols. II, pp. 142-144, y Margarida Sobral Neto, Terra e Conflito. Região de Coimbra, 1700-1834, Viseu, Palimage, 1997, p. 40. Vid. también la síntesis de Antonio Eiras Roel, "Los productos alimentarios de ultramar en la agricultura de los países mediterráneos", Obradoiro de Historia Moderna, 7 (1998), pp. 40 y ss.

${ }^{63}$ Continúa siendo fundamental la obra de Alain Huetz de Lemps, Vignobles et vins du Nord-Ouest de l'Espagne, Burdeos, Institut de Géographie, 1967, 2 vols. La Junta de Castilla y León ha publicado en 2004 una versión en castellano de esta obra, pero mutilada, pues han sido excluidas las abundantes páginas dedicadas al viñedo gallego. 
documentada en los libros de cuentas-, las zonas en las que predominaba un cuasi monocultivo vitícola registraron cambios de menor intensidad y en la etapa final del Antiguo Régimne sufrieron una crisis que se prolongó durante buena parte del siglo XIX.

Todos los monasterios contaban con libros de bodega, aparte de los que llevaban los monjes granjeros destacados en los prioratos (vitícolas o no vitícolas, pero los primeros son los que ahora interesan). La utilidad de sus libros para conocer, no ya la producción, sino las rentas de vino suele ser escasa, porque las bodegas se abastecían a menudo de remesas enviadas desde las granjas -y si era necesario, de compras- ${ }^{64}$, y el volumen de los envíos no dependía sólo de la cosecha, sino también de prácticas relacionadas con la comercialización: a veces ésta se centraba con prelación en la casa central; en otras, se realizaba con preferencia en los prioratos, tal vez para abaratar gastos de transporte. Esta última opción parece haberse impuesto a lo largo del siglo XVIII, a juzgar, por ejemplo, por la información que proporciona el libro de bodega de San Clodio de Leiro, el monasterio que, en términos porcentuales - por relación al total de rentas- mayores ingresos de vino percibía.

Cuadro - Ingresos de la bodega de San Clodio, media anual en hls

\begin{tabular}{|c|c|c|c|c|c|c|c|c|c|c|}
\hline \multirow[t]{2}{*}{ Años } & \multicolumn{4}{|c|}{ a) Ingresos totales } & \multicolumn{6}{|c|}{$\begin{array}{l}\text { b) Excluyendo las cantidades enviadas por el } \\
\text { prior de A Grova }\end{array}$} \\
\hline & Blanco & Tinto & Total & Indice & Blanco & Î́ndice & Tinto & Índice & Total & Índice \\
\hline 1670-79 & 403,8 & 805,9 & $1.209,7$ & 100 & 403,8 & 100 & $354,-$ & 100 & 757,8 & 100 \\
\hline $1680-88$ & 307,2 & $705,-$ & $1.012,2$ & 84 & 307,2 & 76 & 323,1 & 91 & 630,3 & 83 \\
\hline $1689-97$ & $388,-$ & 825,2 & $1.213,2$ & 100 & $388,-$ & 96 & 378,7 & 107 & 766,7 & 101 \\
\hline $1698-1709$ & 282,8 & 510,1 & 92,9 & 66 & 282,8 & 70 & 288,8 & 82 & 571,6 & 75 \\
\hline $1710-20$ & 326,4 & 573,8 & 900,2 & 74 & 326,4 & 81 & 354,2 & 100 & 680,6 & 90 \\
\hline $1721-29$ & 345,3 & 607 & 952,3 & 79 & 281,3 & 70 & 299,3 & 85 & 580,6 & 77 \\
\hline $1730-40$ & 277,4 & 330,6 & 608,0 & 50 & 277,4 & 69 & 306,9 & 87 & 584,3 & 77 \\
\hline $1741-49$ & 306,3 & 354,5 & 660,3 & 55 & 306,3 & 76 & 324,7 & 92 & 631 & 83 \\
\hline $1750-58$ & 289,8 & 327,9 & 617,7 & 51 & 288,3 & 71 & 313,6 & 89 & 601,9 & 79 \\
\hline $1759-70$ & 309,4 & 399,2 & 708,6 & 59 & 309,4 & 77 & 357,8 & 101 & 667,2 & 88 \\
\hline $1771-78$ & 322,9 & 368,2 & 691,1 & 57 & 322,9 & 80 & 368,3 & 104 & 691,1 & 91 \\
\hline $1779-90$ & 334,2 & 421,8 & 756,0 & 62 & 330,5 & 82 & 418,1 & 118 & 748,6 & 99 \\
\hline $1791-98$ & 318,8 & 420,7 & 739,5 & 61 & 318,8 & 79 & 420,7 & 119 & 739,5 & 98 \\
\hline $1799-1810$ & 305,3 & 433,2 & 738,5 & 61 & 305,3 & 76 & 433,2 & 122 & 738,5 & 97 \\
\hline 1811-18 & 253,9 & 359,7 & 613,6 & 51 & 253,9 & 63 & 359,7 & 102 & 613,6 & 81 \\
\hline
\end{tabular}

Fuente: Archivo Histórico Provincial de Ourense, Clero, libro 745 de San Clodio.

${ }^{64}$ Los monasterios que tenían pocas rentas de vino, o consideraban de mala calidad el de sus foros y diezmos, compraban habitualmente cantidades diversas (casos de Monfero, Armenteira, Lourenzá...). En los prioratos no vitícolas, las compras de vino representaban el gasto monetario fundamental del monje granjero y de los criados en alimentación. 
De atender a la trayectoria de las entradas totales, habría que concluir que las rentas de la bodega de San Clodio se redujeron a la mitad desde el último tercio del XVII a la segunda década del XIX, según indican los primeros datos del cuadro (a) Ingresos totales). Ocurre, sin embargo, que la serie referida al vino tinto -y por lo mismo la de los ingresos globales- no es homogénea, al incluir envíos procedentes de la Granja de A Grova, muy cuantiosos hasta 1721-29, más reducidos hasta mediados de siglo, para desaparecer o volverse insignificantes desde 1771-78, debido a que la comunidad optó por una comercialización descentralizada. Si se prescinde de las remesas procedentes de A Grova, se advierte que las rentas de la bodega de San Clodio permanecen estables, con ligeras oscilaciones desde 1670 a 1818 , bien es cierto que esa estabilidad es el resultado de una significativa caída de los ingresos de vino blanco, compensada por el ascenso de las entradas de tinto entre 1771 y 1810 . Las rentas cobradas por la bodega (excluidas las cantidades procedentes de A Grova), no reflejan con fidelidad la trayectoria de la producción, debido a que desde 1713 los monjes optan por una progresiva conversión de foros proporcionales en fijos: hasta ese año no había cargas fijas, y entonces aparecen 19,5 moyos de blanco y 4 de tinto, que en 1750 ya subieron a 95 de cada clase. Estos cambios contribuyen a la estabilidad de las entradas totales. Pero si atendemos a la serie de quintos y diezmos, que desde mediados del XVIII parece conservar la necesaria homogeneidad, se advierte con toda claridad la divergencia entre las trayectorias de la producción de blanco y de tinto desde fines del XVIII:

Cuadro - Quintos y diezmos de la bodega de San Clodio. Media anual en hls

\begin{tabular}{ccccccc}
\hline Años & Blanco & Índice & Tinto & Índice & Total & Índice \\
\hline $1750-58$ & 51,5 & 100 & $77,-$ & 100 & 128,5 & 100 \\
$1759-70$ & 52,2 & 101 & 102,7 & 133 & 154,9 & 121 \\
$1771-78$ & 65,1 & 126 & 110,3 & 143 & 175,4 & 136 \\
$1779-90$ & 69,2 & 134 & $171,-$ & 222 & 240,2 & 187 \\
$1791-98$ & 67,6 & 131 & 159,2 & 207 & 226,8 & 176 \\
$1798-1810$ & 44,8 & 87 & 178,9 & 232 & 223,7 & 174 \\
$1811-18$ & 19,8 & 38 & 96,4 & 125 & 116,2 & 88 \\
\hline
\end{tabular}

Fuente: Archivo Histórico Provincial de Ourense, Clero, libro 745 de San Clodio.

En las tierras en las que el monasterio percibía foros proporcionales y diezmos, la producción vitícola se expande en la segunda mitad del XVIII, pero el incremento afecta sobre todo al vino tinto, ya que el blanco, esfumados los años de buenas cosechas correspondientes a las décadas de 1780-90, entra en declive, o en una verdadera crisis desde 1810, en parte tal vez porque los campesinos arrancaron las cepas de esta calidad y las sustituyeron por otras de 
tinto $^{65}$. Los diezmos que el monasterio de Sobrado percibía en los prioratos de Banga, Gomariz y Moldes, en la cuenca del Avia, y en el de San Bernardo de Tibiás, en la del Arnoia, acreditan esa diferenciada evolución de las cosechas de blanco y tinto en la etapa final del Antiguo Régimen:

Cuadro - Diezmos de vino en Banga, Gomariz y Moldes, y en Tibiás, prioratos de Sobrado

Media anual en hls

\begin{tabular}{crrrrrr|rrrrrr}
\hline \multirow{2}{*}{ Años } & \multicolumn{6}{c|}{ Banga, Gomariz y Moldes } & \multicolumn{5}{c}{ San Bernardo de Tibiás } \\
\cline { 2 - 13 } & Blanco & Índ. & Tinto & Índ. & Total & Índ. & Blanco & Índ. & Tinto & Índ. & Total & Índ. \\
\hline $1640-49$ & 159,8 & 100 & 241,9 & 100 & 401,7 & 100 & 98,8 & 100 & 49,5 & 100 & 148,3 & 100 \\
$1650-59$ & 172,9 & 108 & 288,2 & 119 & 461,1 & 115 & 78,5 & 79 & 54,3 & 110 & 132,8 & 90 \\
$1660-69$ & 164,9 & 103 & 256,8 & 106 & 421,7 & 115 & 59,9 & 61 & 42,8 & 86 & 102,7 & 69 \\
$1670-79$ & 233,5 & 146 & 357,9 & 148 & 591,4 & 147 & 58,7 & 59 & $59,-$ & 119 & 117,7 & 79 \\
$1680-89$ & 114,4 & 72 & 262,5 & 109 & 376,9 & 92 & 60,6 & 61 & 56,8 & 115 & 117,4 & 79 \\
$1690-99$ & 123,9 & 78 & 306,8 & 127 & 430,7 & 107 & $77,-$ & 78 & 51,3 & 104 & 128,3 & 87 \\
$1700-09$ & 119,2 & 76 & 302,1 & 125 & 421,3 & 105 & 63,6 & 64 & 60,1 & 121 & 123,7 & 83 \\
$1710-19$ & 210,1 & 131 & $321,-$ & 133 & 531,1 & 132 & 89,5 & 91 & 91,5 & 185 & $181,-$ & 122 \\
$1720-29$ & 168,0 & 105 & 307,5 & 127 & 475,5 & 118 & 74,3 & 75 & 72,8 & 147 & 147,1 & 99 \\
$1730-39$ & 126,7 & 79 & 256,2 & 106 & 382,9 & 95 & 45,4 & 46 & 41,6 & 84 & $87,-$ & 59 \\
$1740-49$ & 192,2 & 120 & 359,7 & 149 & 551,9 & 137 & 67,3 & 68 & 64,9 & 131 & 132,2 & 89 \\
$1750-59$ & 129,3 & 81 & 295,5 & 122 & 424,8 & 106 & 75,1 & 76 & 43,5 & 88 & 118,6 & 80 \\
$1760-69$ & 110,2 & 69 & 309,4 & 128 & 419,6 & 104 & 67,3 & 68 & 38,8 & 78 & 106,1 & 72 \\
$1770-79$ & 96,6 & 60 & 295,5 & 122 & 392,1 & 98 & 54,1 & 55 & 39,8 & 80 & 93,9 & 63 \\
$1780-89$ & 98,1 & 61 & 295,1 & 122 & 393,2 & 98 & 57,6 & 58 & 47,2 & 95 & 104,8 & 71 \\
$1790-99$ & 84,6 & 53 & $306,-$ & 126 & 390,6 & 97 & 47,9 & 48 & 39,8 & 80 & 87,7 & 59 \\
$1800-09$ & 48,4 & 30 & 277 & 115 & 325,4 & 81 & 40,1 & 41 & 28,9 & 58 & $69,-$ & 47 \\
$1810-19$ & 19,3 & 12 & 214,4 & 89 & 233,7 & 58 & 34,9 & 35 & 28,8 & 58 & 63,7 & 43 \\
$1824-34$ & 53,3 & 33 & 247,9 & 102 & 301,2 & 75 & 51,1 & 52 & 53,3 & 108 & 104,4 & 70 \\
\hline
\end{tabular}

Fuente: Arquivo do Reino de Galicia, Mosteiros, libros 122, 181, 195, 196, 197 y 198 (Banga, Gomariz y Moldes) y 182, 183 y 184 (Tibiás).

Dentro de fluctuaciones que en buena medida derivarán del nivel de las cosechas, la producción global se mantiene estable hasta doblado el siglo XVIII. La crisis afecta entonces de modo acusado al vino blanco, en especial en Banga, Gomariz y Moldes, pero también en Tibiás. Las cosechas de tinto resisten mejor, si bien en los dominios del monasterio de Sobrado no registran la expansión documentada antes en las tierras de San Clodio. De la caída de la producción del blanco y del paralelo deterioro de sus precios relativos se ocuparon algunos contemporáneos, como el canónigo compostelano Pedro Antonio Sánchez en la década de 1780, o el catedrático de Química de la Universidad de Santiago Antonio Casares en 1843. El primero, que escribe hacia 1788, en una coyuntura caracterizada por las abundantes cosechas de tinto,

${ }^{65}$ Información más abundante en Pegerto Saavedra, Das casas de morada, op. cit., pp. 227 y ss. 
señalaba que, debido a la pérdida de los mercados externos, los viticultores gallegos abandonaran las cepas de calidad, para producir tintos destinados a consumidores del Reino: "Otro perjuicio causado por esta falta de extracción ha sido la alteración asombrosa en la calidad de los vinos. Los extranjeros que venían a buscarlos, haciendo solamente aprecio de los exquisitos, estimulaban a los cosecheros al cuidado de procurarlos. Por el contrario, faltando esta extracción, los vinos de buena calidad han quedado casi al nivel de los flojos. Baste para convencerse de esto saber que en la ciudad de Santiago, así como en otros pueblos de Galicia, a todo el vino de Ribadavia que se despacha en las tabernas, señalaba la justicia igual precio para su venta. Así es que los colonos y hacendados, después que se dejó de sacar para fuera del Reino, se han dado indecible prisa en arrancar las buenas castas, y sustituirlas otras que rinden con mucha mayor abundancia, pero que producen un vino muy inferior al antiguo: tanto es lo que ha degenerado, que apenas se puede creer sea este el país de cuyos vinos han hecho tantos elogios los historiadores y los autores médicos, y que han servido no pocas veces de asunto a nuestros poetas" ${ }^{\prime \prime 6}$.

Las series de precios de blanco y tinto confirman de modo resolutivo las afirmaciones de Pedro Antonio Sánchez: la bodega de San Clodio vendía el moyo de blanco un 37,5 por cien más caro que el de tinto en 1680-89; en 1750-59 , la diferencia se redujera al 15 por cien, y a partir de 1790-99 el precio del tinto supera al del blanco (hasta un 29,5 por cien en 1810-14). Algunos datos puntuales del siglo XVI revelan que las diferencias a favor del blanco eran entonces más grandes ${ }^{67}$.

Antonio Casares escribía en 1843 en sus Observaciones sobre el cultivo de la vid en Galicia: "en el día, la mayor parte del vino que se consume es tinto, i los compradores dan comúnmente la preferencia al más cargado de color; i he aquí la causa principal de su alteración, pues el cosechero cuida sólo de esta propiedad del vino, i da poca importancia a la fortaleza, buen gusto i fragancia, que debían ser las cualidades apetecidas; de aquí la preferencia que dan los propietarios a los vidueños mui esquilmeños, que por lo regular son los menos a propósito para producir buenos vinos, porque en este género de cultivo lo

${ }^{66}$ Pedro Antonio Sánchez, "Representación al inmortal rey D. Carlos III sobre la navegación del Miño", reproducido en Pegerto Saavedra, edr., Agricultura e Ilustración. Cónsul Jove, Vicente do Seixo, Pedro A. Sánchez, Felipe Argenti, L. Marcelino Pereira, Santiago de Compostela, Xunta de Galicia (Biblioteca de Clásicos Agrarios), 1999, p. 142.

${ }^{67}$ En las cuentas del conde de Ribadavia, el precio del blanco duplica al del tinto en 1525 -26; lo supera en un 73 por cien en 1568 y en un 40 en 1590. Archivo de la Fundación Ducal de Medinaceli (Sevilla), secc. Ribadavia, legs. 23, 24 y 27, y Pegerto Saavedra, Das casas de morada, op. cit., pp. 249 y ss. 
que se gana en cantidad se pierde en calidad; i de aquí también la adición de moras, boyas de saúco o campeche con el fin de aumentar la materia colorante". También para este autor el cierre de los mercados externos estaba detrás de la alteración de las calidades: "nuestros paisanos, con un paladar menos delicado en este punto que el de los extranjeros, no supieron distinguir las diferentes clases de vino i a todas les señalaron igual precio. Desde entonces los cosecheros no se esmeraron en coger buen vino, sino mucho, para compensar con la cantidad lo que perdían en la desestimación de la calidad"68.

Pedro Antonio Sánchez, varios miembros de las Juntas del Reino que en la segunda mitad del XVIII trataron de los problemas del comercio del vino, Antonio Casares y otros autores estimaban que, de resultas de la ampliación de las superficies plantadas de vides y parras por diversas comarcas del litoral y prelitoral, como las mariñas de Betanzos, el valle del Ulla y las rías baixas, había un exceso de producción que el mercado gallego no podía absorber. No ignoraban tampoco la "falta extracción", esto es, la pérdida de los mercados externos. Y tal parece el problema fundamental: conforme avanza el siglo XVIII los vinos gallegos se ven desplazados de las poblaciones del Cantábrico por los de la Rioja y la cuenca del Duero, más baratos y adaptados a los nuevos gustos (claretes). También ejercieron competencia con éxito en el mercado inglés los vinos de Porto, en franca expansión en la segunda mitad del XVII, pero Inglaterra constituía una salida secundaria para los vinos gallegos. ${ }^{69}$

Lo que las fuentes no acreditan es esa supuesta expansión de la producción vitícola en las mariñas y las rías, en donde el vino constituía un cultivo más, al lado de los cereales. En los prioratos de las Cascas y San Martiño do Porto, mientras aumenta notablemente la producción de cereales -en buena medida gracias al maíz, como quedó demostrado atrás-, las cosechas de vino varián poco desde mediados del XVII a la desamortización, lo que significa que en el sistema agrario el vino pierde terreno en beneficio del pan:

${ }^{68}$ A. Casares Rodríguez, Observaciones sobre el cultivo de la vid en Galicia, Santiago de Compostela, Imp. de la Viuda e Hijos de Compañel, 1843, p. 29.

${ }^{69}$ Cf.Alain Huetz de Lemps, "Apogeo y decadencia de un viñedo de calidad: el de Ribadavia", Anuario de Historia Económica y Social, 1 (1968), pp. 207-225. Sobre el vino de Porto, Aurélio de Oliveira, Niveis de produção vitícola no Entre Douro e Minho, 1629-1822, Porto, 1986; y José Vicente Serrao, "O quadro económico. Configuraçoes estruturais e tendências de evolução", en José Mattosso, dir., Historia de Portugal. Quarto volume. O Antigo Regime (1620-1807), Lisboa, Círculo de Leitores, 1993, p. 80, con una serie de las cantidades de vino exportado a Inglaterra (la fase de expansión va de 1675 a 1719), y Antonio Barros Cardoso, Baco e Hermes. O Porto e Comercio Interno e Externo de Vinhos do Douro (1700-1756), Porto, Grupo de Estudos de História da Viticultura Auriense, 2003, 2 vols. 
Cuadro - Trayectoria de las rentas proporcionales de cereales y de vino en los prioratos de Las Cascas y de San Martiño do Porto. Media anual en hls

\begin{tabular}{ccccccc}
\hline \multirow{2}{*}{ Años } & \multicolumn{3}{c}{ Las Cascas } & \multicolumn{3}{c}{ San Martiño do Porto } \\
\cline { 2 - 7 } & Cereales & Vino & \% de vino & Cereales & Vino & $\%$ de vino \\
\hline $1620-29$ & 25,6 & 24,9 & 49,4 & - & - & - \\
$1630-39$ & 34,3 & 29 & 45,8 & - & - & - \\
$1640-49$ & 55,7 & 23,3 & 29,5 & 81,3 & 57,5 & 41,4 \\
$1650-59$ & 62,4 & 39,1 & 38,5 & 77,4 & 70,6 & 47,7 \\
$1660-69$ & 60,3 & 79,6 & 56,9 & 113,9 & 80,7 & 41,5 \\
$1670-79$ & $76,-$ & 74,1 & 49,4 & 93,7 & $60,-$ & $39,-$ \\
$1680-89$ & 81,9 & 46,7 & 36,3 & 145,8 & 58,2 & 28,5 \\
$1690-99$ & 76,7 & $46,-$ & 37,5 & 138,7 & 62 & 30,9 \\
$1700-09$ & 94,3 & 51,4 & 35,3 & 119,7 & 72,3 & 37,7 \\
$1710-19$ & 106,9 & 49 & 29,2 & 160,1 & 72,9 & 31,3 \\
$1720-29$ & 155,1 & 27,8 & 15,2 & 168,8 & 48,9 & 22,5 \\
$1730-39$ & 162,1 & 25,6 & 13,6 & 166,8 & 44,3 & $21,-$ \\
$1740-49$ & 149,7 & 31,6 & 17,4 & 161,6 & 79,6 & $33,-$ \\
$1750-59$ & 138,8 & 34,7 & $20,-$ & 211,2 & 55,9 & 20,9 \\
$1760-69$ & 150,4 & 38,1 & 20,2 & 248,9 & 69,1 & 21,7 \\
$1770-79$ & 175,4 & 38,9 & 18,2 & 209,5 & 65 & 23,7 \\
$1780-89$ & 217,6 & 52,3 & 19,4 & 271,7 & 89,4 & 24,8 \\
$1790-99$ & 132,1 & 42,3 & 24,3 & 242,5 & 53,6 & 18,1 \\
$1800-09$ & 108,9 & 35,1 & 24,4 & 218,5 & 82,1 & 27,3 \\
$1810-19$ & 136,6 & 19,1 & 12,3 & 225,4 & 35,8 & 13,7 \\
$1824-34$ & 146,3 & 34,8 & 19,2 & 243,8 & 48,1 & 16,5 \\
\hline
\end{tabular}

Fuente: Arquivo do Reino de Galicia, Mosteiros, libros 237 y 238 (Cascas) y 122 y 132 (San Martiño do Porto).

Nada permite afirmar que la producción de vino se expandiese de forma significativa en la etapa final del Antiguo Régimen; es cierto que, en especial en la década de 1780, se registran años de buenas cosechas -igualmente de cerealespero también las hay a mediados del XVII y en cualquier caso, en términos porcentuales el vino va perdiendo importancia en la economía campesina, más orientada a los cereales. Algo parecido sucede en las rías baixas, por lo que pudimos comprobar en el gran priorato de O Rosal (de Oia) y en la granja de Vigo (de Melón). Asimesmo, en los prioratos del Ribeiro, según quedó indicado, los campesinos trataron de hacer frente a la crisis de la economía vitícola cultivando sobre todo maíz, aunque las condiciones edafológicas de cada aldea hacían que los resultados del empeño variasen. En el priorato de Moldes los lugareños logran un cierto éxito: si en 1740-59 el vino representaba el 75 por cien del volumen de la masa decimal, y los cereales el 25 por cien, en 1800-34 los porcentajes eran, por el mismo orden, del 35 y del 65 (por la expansión del maíz, pero también por la aguda crisis de la producción de vino) ${ }^{70}$.

${ }^{70}$ Pegerto Saavedra, Das casas de morada, op. cit., pp. 242 y ss., con series de producción de vino de las Rías Baixas. 
De todas formas, la trayectoria de la producción global de vino en las diversas comarcas de Galicia no está suficientemente esclarecida. La serie de ingresos del gran monasterio de Oseira es la más completa que se conserva en la documentación monástica consultada, por abarcar dos siglos largos y por referirse a las rentas globales cobradas en los diversos prioratos y granjas de la comunidad.

Cuadro - Ingresos globales de vino del monasterio de Oseira. Medias anuales en hls

\begin{tabular}{cccc}
\hline Años cosecha & Hls & Índice & Índice ingresos de centeno \\
\hline $1617-28$ & 1.561 & 100 & 100 \\
$1629-37$ & $1.999,4$ & 128 & 104 \\
$1638-49$ & $1.936,-$ & 124 & 108 \\
$1650-58$ & $2.010,9$ & 129 & 108 \\
$1659-67$ & $2.215,8$ & 142 & 107 \\
$1668-79$ & $2.348,4$ & 150 & 114 \\
$1680-88$ & $1.930,4$ & 124 & 112 \\
$1689-97$ & $2.064,4$ & 132 & 112 \\
$1698-1709$ & $2.212,4$ & 142 & 113 \\
$1710-20$ & $2.234,8$ & 143 & 110 \\
$1721-29$ & $2.270,2$ & 145 & 113 \\
$1730-40$ & $2.074,4$ & 133 & 111 \\
$1741-49$ & $2.481,7$ & 159 & 119 \\
$1750-58$ & $2.574,9$ & 165 & 113 \\
$1759-70$ & $2.698,8$ & 172 & 112 \\
$1771-78$ & $2.770,7$ & 177 & 119 \\
$1779-90$ & $2.948,-$ & 189 & 117 \\
$1791-98$ & $2.664,5$ & 171 & 113 \\
$1799-1810$ & $2.427,7$ & 156 & 110 \\
$1811-18$ & $1.794,5$ & 115 & 123 \\
$1824-31$ & $2.398,2$ & 154 & \\
\hline
\end{tabular}

Fuente: Biblioteca del Monasterio de Poio. Libro de Estado de Oseira.

La casa abacial, situada tierras relativamente altas y productoras de centeno, no tenía rentas de vino, y el que entraba en la bodega procedía de una docena de administraciones radicadas en su mayoría en las riberas del Miño y procedía en lo fundamental de foros proporcionales a la cosecha, diezmos y de rentas fijas, aunque los porcentajes de cada partida rara vez se especifican en la fuente.

En 1738-40, por ejemplo, las rentas fijas representaban el 39 por cien de las entradas totales, y los diezmos, cuartos, quintos y sextos, el 52 por cien; en 1807-18 los porcentajes fueron, por el mismo orden, del 51 y 48, y en 1824-31 del 44 y del 55, por la recuperación vigorosa de los diezmos en esa década. En cualquier caso, las rentas fijas ascendían a 614,5 moyos a mediados del XVIII, y a 701,75 -un 14 por cien más- en vísperas de la exclaustración, y aquí radica probablemente una parte de la explicación de la tendencia alcista de los índices desde comienzos del XVII a fines del XVIII y del buen nivel que 
mantienen en los años inmediatos a la desamortización. Sin duda hubo también un aumento de la producción, que culmina con las excelentes cosechas de la década de 1780 , pero no parece que la serie pueda tomarse como indicador de la trayectoria del conjunto de la economía vitícola de Lugo y Ourense, pues ya se vio que los ingresos decimales de prioratos de Sobrado, sitos en el Ribeiro de Avia, descienden desde la primera mitad del XVIII. En el Ribeiro de Ourense y en el valle del Sil, en donde radicaban los dominios de Oseira, la producción aguantó mejor, e incluso se incrementó en algún caso en la fase final del Antiguo Régimen, lo que contribuye a explicar la tendencia de las cifras del cuadro ${ }^{71}$.

Los ingresos globales de vino se caracterizan por dinamismo mucho más acusado que los de centeno. Mientras los primeros se incrementaron un 75 por cien entre principios del XVII y fines del XVIII, los de cereal apenas lo hicieron en un 20 por cien. La mayor vinculación orgánica que existía entre rentas y producción y el aumento de las rentas fijas percibidas en vino dan razón de las diferentes trayectorias. Con todo, los ingresos de centeno fueron siempre mucho más voluminosos que los de vino: 5.175 hls frente a 1.560 en $1617-28 ; 6.235$ frente a 2.576 en 1750-58, y 6.350 contra 2.400 en 1824-31. Eso sí, a las puertas de la exclaustración nada autoriza a hablar de crisis en lo referido a la cuantía y percepción de los principales capítulos de ingresos del poderoso cenobio de Oseira, tanto de vino como de cereal, lo que ha de atribuirse a factores productivos, pero también a otros de orden social todavía mal conocidos. Lo cierto es que conocemos mejor las transformaciones agrarias y su diferente repercusión en los ingresos de los estamentos rentistas -en este caso de los monasterios cistercienses-, que los mecanismos a través de los cuales las poderosas comunidades de regulares consiguieron cobrar a lo largo de siglos cuantiosas rentas sin suscitar, ni siquiera desde 1808, una conflictividad generalizada ${ }^{72}$.

Recebido em/Submitted on: 21/02/2011

Aceite em/Approved on: 30/03/2011

${ }^{71}$ Las series proporcionales a la cosecha conservadas para la etapa final del Antiguo Régimen no tienen una tendencia homogénea; vid. la amplia información que aporta Isolina Rionegro Fariña, Estructura económica del císter orensano, op. cit., pp. 274 y ss.

${ }^{72}$ Lo que no significa que no hubiese resistencias y hasta motines puntuales: de ello nos ocuparemos en una monografía de próxima publicación sobre los cistercienses de Galicia. 